\title{
Differential Regulation of Gene Expression of Alveolar Epithelial Cell Markers in Human Lung Adenocarcinoma-Derived A549 Clones
}

\author{
Hiroshi Kondo, ${ }^{1,2}$ Keiko Miyoshi, ${ }^{1}$ Shoji Sakiyama, ${ }^{2}$ Akira Tangoku, ${ }^{2}$ and Takafumi Noma ${ }^{1}$ \\ ${ }^{1}$ Department of Molecular Biology, Institute of Health Biosciences, The University of Tokushima Graduate School, \\ 3-18-15 Kuramoto-cho, Tokushima 770-8504, Japan \\ ${ }^{2}$ Department of Thoracic and Endocrine Surgery and Oncology, Institute of Health Biosciences, \\ The University of Tokushima Graduate School, 3-18-15 Kuramoto-cho, Tokushima 770-8504, Japan \\ Correspondence should be addressed to Takafumi Noma; ntaka@tokushima-u.ac.jp
}

Received 8 January 2015; Revised 10 April 2015; Accepted 21 April 2015

Academic Editor: Hannele T. Ruohola-Baker

Copyright (C) 2015 Hiroshi Kondo et al. This is an open access article distributed under the Creative Commons Attribution License, which permits unrestricted use, distribution, and reproduction in any medium, provided the original work is properly cited.

\begin{abstract}
Stem cell therapy appears to be promising for restoring damaged or irreparable lung tissue. However, establishing a simple and reproducible protocol for preparing lung progenitor populations is difficult because the molecular basis for alveolar epithelial cell differentiation is not fully understood. We investigated an in vitro system to analyze the regulatory mechanisms of alveolus-specific gene expression using a human alveolar epithelial type II (ATII) cell line, A549. After cloning A549 subpopulations, each clone was classified into five groups according to cell morphology and marker gene expression. Two clones (B7 and H12) were further analyzed. Under serum-free culture conditions, surfactant protein C (SPC), an ATII marker, was upregulated in both H12 and B7. Aquaporin 5 (AQP5), an ATI marker, was upregulated in $\mathrm{H} 12$ and significantly induced in B7. When the RAS/MAPK pathway was inhibited, SPC and thyroid transcription factor-1 (TTF-1) expression levels were enhanced. After treatment with dexamethasone (DEX), 8bromoadenosine $3^{\prime} 5^{\prime}$-cyclic monophosphate (8-Br-cAMP), 3-isobutyl-1-methylxanthine (IBMX), and keratinocyte growth factor (KGF), surfactant protein B and TTF-1 expression levels were enhanced. We found that A549-derived clones have plasticity in gene expression of alveolar epithelial differentiation markers and could be useful in studying ATII maintenance and differentiation.
\end{abstract}

\section{Introduction}

Lung diseases such as chronic obstructive pulmonary disease and idiopathic pulmonary fibrosis can be life threatening. Until now, lung transplantation has been the treatment of choice for the severe cases [1]. However, lung transplantation is associated with several problems, including issues with histocompatibility and a shortage of donors. Therefore, regenerative medicine of the lungs using stem cells is attracting a lot of attention as a promising therapy $[2,3]$. Recently, embryonic stem cells (ESCs) and induced pluripotent stem cells (iPSCs) have been used to study the possible regeneration of alveolar epithelial type (AT) cells $[4,5]$. Differentiation into AT cells from ESCs and iPSCs still needs to pass through the several developmental stages, and the regulation of this developmental process remains unclear.
Thus, it is required to establish a simple and reproducible model system to understand the molecular basis of the differentiation of divergent progenitor populations in the human lung and to further develop lung regenerative therapy.

Lung alveoli, which are essential for respiratory function, are composed of two types of alveolar epithelial cells, that is, type I (ATI) and type II (ATII). ATI cells are flat cells that cover $95 \%$ of alveoli, and they are involved in the exchange oxygen and carbon dioxide [6, 7]. These cells express specific differentiation markers, such as aquaporin 5 (AQP5 $[8,9]$ ), caveolin-1 [10], and the receptor for advanced glycation end products [11]. ATII cells are cuboidal cells and produce surfactant, which consists of proteins such as surfactant proteins $\mathrm{A}, \mathrm{B}, \mathrm{C}$, and D (SPA, SPB, SPC, and SPD), and phospholipids. These surfactants are essential for maintenance of alveoli and host defense [12-14]. SPA, SPB, 
and SPD are synthesized in both Clara cells and ATII cells. SPC is synthesized only in ATII cells and, therefore, is a specific marker for ATII cells [15]. The cell-type-specific expressions of SPB and SPC in Clara and ATII cells are required for lung respiratory function $[16,17]$. Both gene expressions are regulated by thyroid transcription factor 1 (TTF-1) during lung development [18-20]. ATII cells have the stem cell-like properties of self-renewal, proliferation, and differentiation into ATI cells following injury [21-26]. Therefore, it is quite important to prepare a simple and reproducible ATII cell model system and establish a protocol to control the differentiation into ATI cells.

In this study, we used a human non-small cell lung cancerderived cell line, A549, to explore the possibility whether A549 cells are suitable for investigating the regulation of gene expression of differentiation markers. A549 cells are well studied and known to have both K-RAS mutations (G12S) and epidermal growth factor receptor (EGFR) gene amplification [27-29]. A549 cells retain some of the properties of ATII cells but do not express some genes such as TTF-1 [30-32]. However, A549 cells have also been reported to have morphological heterogeneity with various proliferative activities [33] and are not sensitive to differentiation stimuli, for example, insulin/dexamethasone (DEX) treatment [34]. Therefore, we first isolated A549 clones and investigated their gene expression patterns in response to several differentiation stimuli. We found that A549 clones responded reproducibly to their stimuli, showing the plasticity in the gene expression of differentiation markers. These findings indicated that A549 clones could be used for an in vitro system to study molecular basis of AT cells differentiation.

\section{Materials and Methods}

2.1. Cell Cultures. A549 cells, a human non-small cell lung carcinoma cell line, were cultured in Dulbecco's modified Eagle's medium (DMEM, Nissui, Tokyo, Japan) containing $10 \%$ fetal bovine serum (FBS, JRH, Bioscience, Lenexa, KS, USA) at $37^{\circ} \mathrm{C}$ in a $5 \% \mathrm{CO}_{2}$ incubator. For maintenance, A549 cells were passaged at $70 \%$ confluence, and medium was changed every 3 days. Hereafter, the original A549 cells are referred to as parental cells and cloned cells are referred to as "clones" with individual letters and numbers.

\subsection{Characterization of A549 Clones}

2.2.1. Single Cell Cloning. A549 clones were isolated by limiting dilution of A549 cells. Briefly, A549 cells were washed twice with phosphate-buffered saline without calcium and magnesium $[\mathrm{PBS}(-)]$ and dissociated with $0.083 \%$ trypsin (Sigma-Aldrich, Tokyo, Japan) and $0.177 \mathrm{mM}$ ethylenediaminetetraacetic acid. Cell numbers were counted with trypan blue staining. The cells were seeded at 0.3 or 1 cell/well into two 96-well plates. When each isolated clone was grown to $80 \%$ confluence, the cells were sequentially transferred into 24-well plates, 6 -well plates, and $6 \mathrm{~cm}$ dishes.

2.2.2. Morphological Analysis of A549 Clones. Morphology of A549 cell clones was observed using optical microscope
(CKX41N 31PHP; Olympus Corporation, Tokyo, Japan), and the images were captured using a digital microscope camera (DS-Fi2-L3; Nikon, Tokyo, Japan). The thickness of the cells was analyzed by the mean gray value using ImageJ (National Institute of Health, Bethesda, MD, USA) as follows: thin, $<5$; thick, $\geq 5$. The boundary of cell clusters was evaluated by smoothness of the cell cluster outline as follows: "clear" was a smoothly drawn cluster outline and "unclear" was a hard to draw cluster outline. The cell density was evaluated by cell numbers within the frame of $100 \mu \mathrm{m} \times 100 \mu \mathrm{m}$ at $70 \%$ confluence and evaluated as follows: high, $\geq 10$ cells; low, $<10$ cells. The number of cell clusters was observed as the clustering feature at 1 day after passage using high, $\geq 3$; low, $<3$.

2.2.3. Gene Expression Analysis. The levels of gene expression were determined by reverse transcription polymerase chain reaction (RT-PCR). Briefly, total RNA was extracted from the cells using Tri Reagent (Molecular Research Center, Cincinnati, OH, USA) following the manufacturer's protocol. RT was performed using RNA PCR kit AMV ver. 3.0 (TaKaRa, Shiga, Japan). Synthesized cDNA was used for PCR using Go Taq DNA Polymerase (Promega, Madison, WI, USA). Gene-specific primers and PCR conditions are listed in Table 1. To detect TTF-1 expression, PCR was performed by 30 cycles for the initial characterization of clones (Figure 1 and Table 2) and 40 cycles in the other experiments. To detect SPC expression, the primer set of SPC1 was only used for the characterization of clones (Figure 1 and Table 2), and the primer set of SPC2 was used in the other experiments.

2.2.4. Densitometric Analysis. The expression level of each transcript was normalized by that of $18 S$ ribosomal $R N A$ (18SrRNA). The images of the electropherogram were captured using ChemiDoc XRS (BIO-RAD, Hercules, CA, USA), and volume analysis was performed using Quantity One (BIO-RAD). The relative ratio was calculated by time 0 as 1. In the case of no expression signals at time 0 , the relative ratio was calculated by the lowest expression level among the samples as 1 .

2.3. Cell Proliferation Assay. The proliferative activity of the cells was evaluated by counting cell numbers at the indicated time points using trypan blue and Luna-FL Dual Fluorescence Cell Counter (Logos Biosystems, Inc., GyunggiDo, Korea).

\subsection{Induction of Cell Differentiation}

2.4.1. Serum-Free System in Culture. Approximately $4.2 \times 10^{5}$ cells of the A549 cell clones, B7 and H12, were seeded in 6-well plates in DMEM containing 10\% FBS. After the cells reached $70 \%$ confluence, they were washed twice with PBS(-), and DMEM without FBS was added. Cell numbers were counted at $12,24,48,72,96$, and $120 \mathrm{~h}$. For RT-PCR analysis, the cells were harvested every $24 \mathrm{~h}$.

2.4.2. Stimulation of Epidermal Growth Factor Receptor (EGFR) Signaling Pathway. B7 and H12 were seeded in 6-well plates in DMEM containing 10\% FBS. After the cells reached 
TABLE 1: Primers used for RT-PCR.

\begin{tabular}{|c|c|c|c|c|}
\hline Gene & Primer & Annealing $\left({ }^{\circ} \mathrm{C}\right)$ & Cycle & Expressed cells \\
\hline FLK & $\begin{array}{l}\text { F: } 5^{\prime} \text {-AAGGCTCAAACCAGACAAGC-3' } \\
\text { R: } 5^{\prime} \text {-TTCCTGCTGGTGGAAAGAAC-3 }\end{array}$ & 58 & 30 & \multirow[b]{2}{*}{ Early mesoderm } \\
\hline PDGFR $\alpha$ & $\begin{array}{l}\text { F: 5'-GGGGAGAGTGAAGTGAGCTG-3' } \\
\text { R: } 5^{\prime} \text {-AGTCTCGGGATCAGTTGTGC-3 } 3^{\prime}\end{array}$ & 58 & 30 & \\
\hline FOXA2 & $\begin{array}{l}\text { F: } 5^{\prime} \text {-CCGGATCGAGGACAAGTGAG-3' } \\
\text { R: } 5^{\prime} \text {-CAACAACAGCAATGGAGGAG-3' }\end{array}$ & 58 & 30 & \multirow{2}{*}{ Endoderm } \\
\hline SOX17 & $\begin{array}{l}\text { F: } 5^{\prime} \text {-AAGGGCGAGTCCCGTATCC-3' } \\
\text { R: } 5^{\prime} \text {-TTGTAGTTGGGGTGGTCCTG-3' }\end{array}$ & 58 & 30 & \\
\hline TTF-1 & $\begin{array}{l}\text { F: } 5^{\prime} \text {-ACCAGGACACCATGAGGAAC-3' } \\
\text { R: } 5^{\prime} \text {-GCGCCGACAGGTACTTCTG-3' }\end{array}$ & 58 & 30,40 & Lung progenitor \\
\hline p63 & $\begin{array}{l}\text { F: 5' }{ }^{\prime} \text {-TTGCCCCTCCTAGTCATTTG-3' } \\
\text { R: 5' -TACTGTCCGAAACTTGCTGC-3' }\end{array}$ & 58 & 33 & Basal \\
\hline FOXJ1 & $\begin{array}{l}\text { F: 5'-TGGATCACGGACAACTTCTG-3' } \\
\text { R: 5'-AAGTTGCCTTTGAGGGGTTC-3' }\end{array}$ & 58 & 40 & Ciliated \\
\hline MUC5AC & $\begin{array}{l}\text { F: 5'-TACGTGTTCTCCGAGCACTG-3' } \\
\text { R: } 5^{\prime} \text {-GGTTCCACATGAGGACAAGG-3' }\end{array}$ & 58 & 30 & Goblet \\
\hline CC10 & $\begin{array}{l}\text { F: } 5^{\prime} \text {-GTCACACTGGCTCTCTGCTG-3' } \\
\text { R: } 5^{\prime} \text {-GAGCAGTTGGGGATCTTCAG-3' }\end{array}$ & 58 & 40 & Clara \\
\hline AQP5 & $\begin{array}{l}\text { F: } 5^{\prime} \text {-ATCTTCGCCTCCACTGACTC-3' } \\
\text { R: } 5^{\prime} \text {-TTTCTTCTTTTCCCCCTTGG-3' }\end{array}$ & 56 & 40 & \multirow{2}{*}{ Alveolar type I } \\
\hline$T 1 \alpha$ & $\begin{array}{l}\text { F: } 5^{\prime} \text {-TGGGGTCTTACTAGCCATCG-3' } \\
\text { R: } 5^{\prime} \text {-TAGAGGAGCCAAGTCTGGTG-3' }\end{array}$ & 58 & 40 & \\
\hline CFTR & $\begin{array}{l}\text { F: } 5^{\prime} \text {-GCCAGCGTTGTCTCCAAAC- } 3^{\prime} \\
\text { R: } 5^{\prime} \text {-CGATAGAGCGTTCCTCCTTG-3' }\end{array}$ & 58 & 30 & \multirow{4}{*}{ Alveolar type II } \\
\hline$S P B$ & $\begin{array}{l}\text { F: } 5^{\prime} \text {-AAGTTCCTGGAGCAGGAGTG-3' } \\
\text { R: } 5^{\prime} \text {-AGAGGAATGGGGAATTGCTG-3' }\end{array}$ & 58 & 40 & \\
\hline SPC1 & $\begin{array}{l}\text { F: } 5^{\prime} \text {-TTGGTCCTTCACCTCTGTCC-3' } \\
\text { R: } 5^{\prime} \text {-CTCCCACAATCACCACGAC-3' }\end{array}$ & 58 & 40 & \\
\hline SPC2 & $\begin{array}{l}\text { F: 5'-AACGCCTTCTTATCGTGGTG-3' } \\
\text { R: } 5^{\prime} \text {-AAGACTGGGGATGCTCTCTG-3' }\end{array}$ & 58 & 35 & \\
\hline$C D 133$ & $\begin{array}{l}\text { F: 5'-GCAGGGATTATTCTATGCTGTG-3' } \\
\text { R: 5'-ACGCCTTGTCCTTGGTAGTG-3' }\end{array}$ & 58 & 35 & Cancer stem \\
\hline$H I F-1 \alpha$ & $\begin{array}{l}\text { F: } 5^{\prime} \text {-TGCTCATCAGTTGCCACTTC-3' } \\
\text { R: } 5^{\prime} \text {-TCTCATTTCCTCATGGTCAC-3' }\end{array}$ & 56 & 30 & Cancer \\
\hline $18 S r R N A$ & $\begin{array}{l}\text { F: } 5^{\prime} \text {-TACCTGGTTGATCCTGCCAGTAGGAT-3' } \\
\text { R: } 5^{\prime} \text {-CCCGTCGGCATGTATTAGCTCTAGAA-3' }\end{array}$ & 58 & 17 & \\
\hline
\end{tabular}

$70 \%$ confluence, they were washed twice with $\operatorname{PBS}(-)$, changed into DMEM without FBS, and human EGF (10, 30, and 90 ng/mL; Pepro Tec, Rocky Hill, NJ, USA) was added. For RT-PCR analysis, the cells were harvested every $24 \mathrm{~h}$.

2.4.3. Inhibition of RAS/Mitogen-Activated Protein Kinase (MAPK) Signaling Pathway. B7 and H12 were seeded in 6well plates in DMEM containing 10\% FBS. After the cells reached $70 \%$ confluence, they were first treated with the selective MEK1/2 inhibitor U0126 (3, 10, and $30 \mu \mathrm{M}$; Wako, Osaka, Japan) or the MEK1 inhibitor PD98059 (30, 60, and $90 \mu \mathrm{M}$; Wako) in DMEM containing 10\% FBS. Cell numbers were counted at 12, 24, and $48 \mathrm{~h}$. For RT-PCR, the cells were treated with U0126 (10 and $30 \mu \mathrm{M})$ or PD98059 $(90 \mu \mathrm{M})$ and were harvested at 24 and $48 \mathrm{~h}$.
2.4.4. Combination with MEK Inhibitor and DEX-[8-BRcAMP]-IBMX-KGF (DCIK) Treatment. B7 and $\mathrm{H} 12$ were seeded into 6-well plates in DMEM containing 10\% FBS. After the cells reached $70 \%$ confluence, they were first treated with U0126 $(30 \mu \mathrm{M})$ in DMEM containing 10\% FBS. After $24 \mathrm{~h}$, they were washed twice with $\operatorname{PBS}(-)$, and the medium was changed to DMEM without FBS \pm DEX $(50 \mathrm{nM}$; Wako), 8-Br-cAMP (0.1 mM; Sigma-Aldrich), isobutyl-1methylxanthine ([IBMX], 0.1 mM; Wako), and keratinocyte growth factor ([KGF], $50 \mathrm{ng} / \mathrm{mL}$; Wako) for 3 days. DCIK control was cells without DCIK. The cells were then washed twice with PBS(-) and cultured in DMEM with or without FBS for an additional 3 days.

2.5. Statistics. Statistical analysis was performed by Student's $t$-test using Microsoft Excel software. The $p$ value less than 0.05 indicates being statistically significant. 


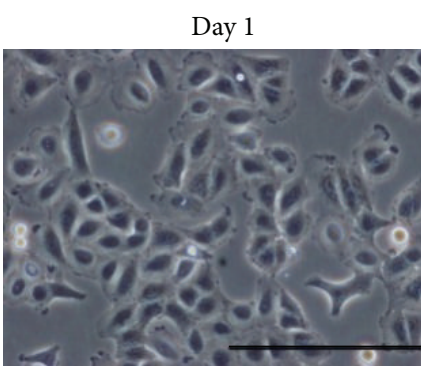

Day 3

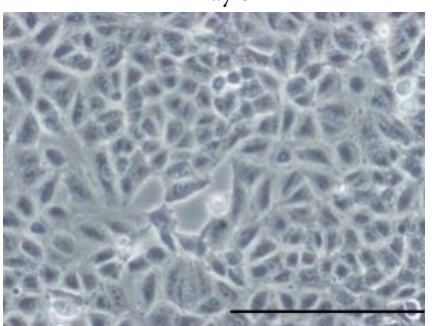

(a)

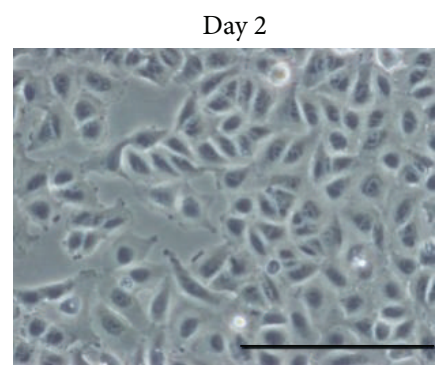

Day 4

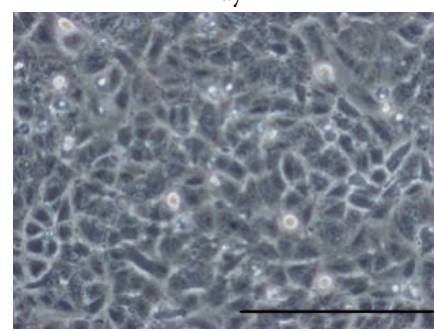

(a)
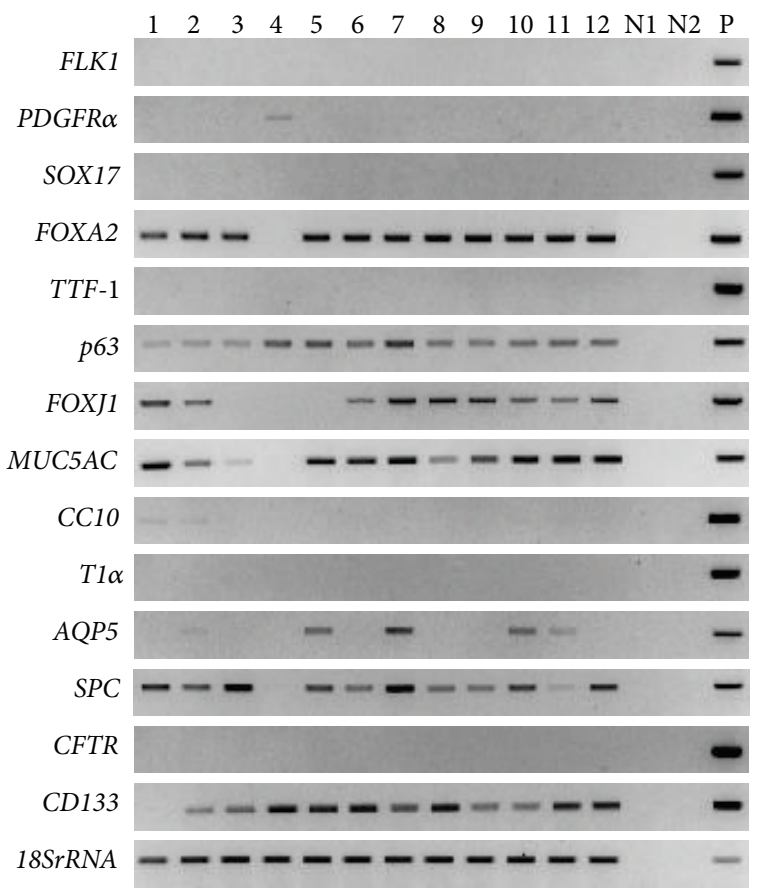

(c)

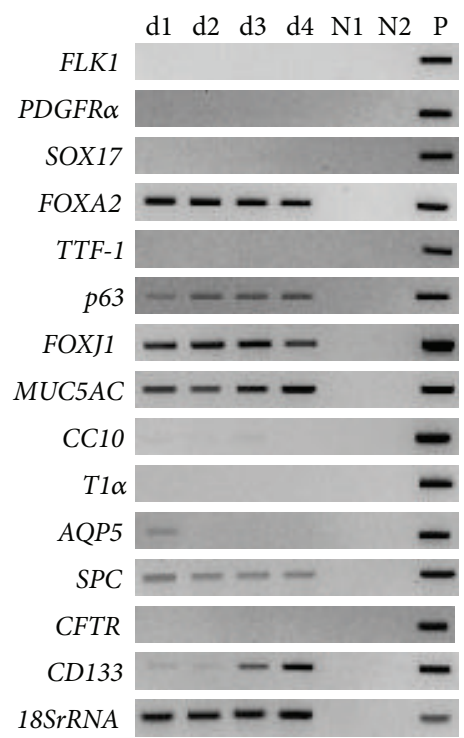

(b)
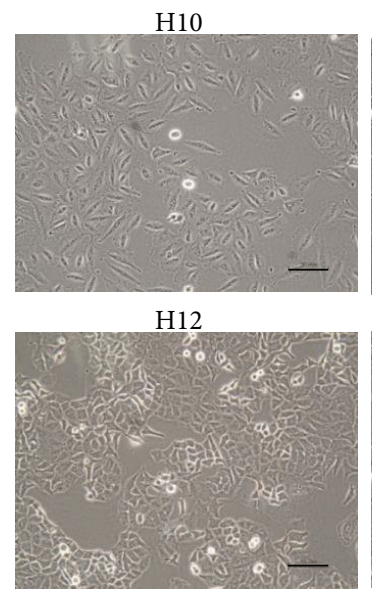

G9

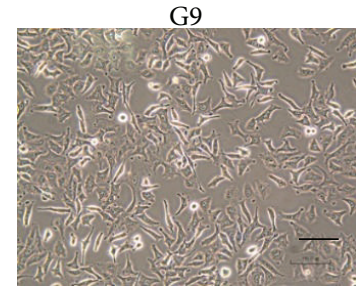

(d)

Figure 1: Characterization of A549 cells. (a) Representative morphology of A549 parental cells during growing phase. Cells were monitored for 4 days after passage. Scale bars: $100 \mu \mathrm{m}$. (b) Gene expression of A549 parental cells shown in (a). 18SrRNA was used as the internal control. d1 to d4: day 1-day 4 shown in (a), N1: negative control of PCR products without RT reaction, N2: negative control with distilled water, and P: positive control with sequenced PCR products in plasmid. (c) Gene expression of A549 clones. The number indicated the group of clones as shown in Table 3. N1, N2, and P are the same symbols as in (b). (d) Representative morphology of A549 clones at 70\% confluence. A549 clones were classified into five groups as shown in Table 4 and selected the representative clones. Scale bars: $100 \mu \mathrm{m}$.

\section{Results}

3.1. Characterization of A549 Parental Cells and Clones. To analyze the characteristics of A549 parental cells, we first observed their morphology in the growing phase for 4 days after seeding. As shown in Figure 1(a), we detected several variations of morphologies in A549 parental cells. We concurrently examined the expression patterns of 14 differentiation marker genes using one of the paired experimental sets (Figure 1(b)) and summarized the results in Table 2. We found that the forkhead box genes, that is, FOXJ1 and FOXA2, transformation-related protein 63 (p63), mucin-5AC 


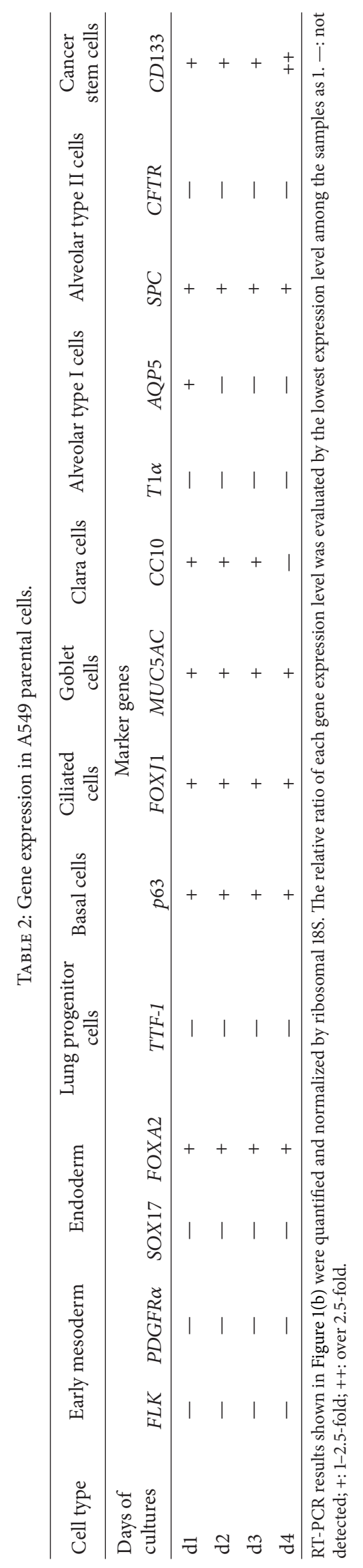


$(M U C 5 A C)$ which is a goblet cell marker, and SPC were constantly expressed at the similar levels throughout the culture period. These genes are the specific markers for endoderm cells, basal cells, ciliated cells, goblet cells, and ATII cells, respectively. Aquaporin 5 (AQP5), a marker for ATI cells, was expressed on day 1 only, and Clara cells $10 \mathrm{kDa}$ secretory protein (CC10), a marker for Clara cells, was slightly expressed on days 1-3 during the growing phase. Expression of Prominin-1 (CD133), a marker for cancer stem cells, was enhanced with the days of culture. To obtain clones from A549 parental cells, we next performed limiting dilution and 46 clones were isolated. We classified these clones into 12 groups according to morphological differences. The average number of days to obtain a confluent monolayer of each clone was 3.7 except for clone G8 cells (14 days). Other morphological characteristics of each clone, including cell thickness, appearance of cell cluster boundaries, cell density, and clustering, were observed and are shown in Table 3. We further examined the expression profiles of marker genes using representative clones from each group (Figure 1(c)). Expressions of FLK1, SOX17, TTF-1, T1 $\alpha$, and CFTR were not detected in all clones. In contrast, all clones expressed $p 63$. Clone G8 in group 4 uniquely expressed the gene encoding platelet-derived growth factor receptor $\alpha$ (PDGFR $\alpha)$, but did not express FOXA2, MUC5AC, or CD133. FOXJ1 was not expressed in groups 3,4 , and 5. CC10 was slightly expressed only in groups 1 and 2. AQP5 was expressed only in groups $2,5,7,10$, and 11 , and $S P C$ was detected in all of them except group 1.

Based on these data, we further classified them into five classes, as shown in Table 4 . The representative cell morphology was demonstrated in Figure 1(d). H10 in class 1 was spindle shaped with a slim nucleus. MUC5AC, a goblet cell marker, was highly expressed, but SPC and AQP5 were not detected in H10. G8, in class 2, grew slowly and showed a piled-up growth. $S P C, p 63$, and PDGFR $\alpha$ were expressed, but FOXA2, MUC5AC, and CD133 were not detected. H12, in class 3 , had a tendency to cluster and the outline of the cell cluster boundary was bright and clearly visible. The cells expressed both $A Q P 5$ and $S P C$, which are typical markers for ATI cells and ATII cells, respectively. B7, in class 4, was polygonal shaped with high cell density but the outline of the cell boundaries was unclear. B7 expressed SPC, but not AQP5. G9 in class 5 shared similar gene expression patterns with B7 but showed invadopodia-like structures.

The gene expression pattern shown in Table 4 suggested that B7 had ATII-like characteristics, and H12 had both ATIlike and ATII-like characteristics. These clones were used for further analyses as potential representatives of ATII and ATI/ATII, respectively.

3.2. Effects of Serum Depletion on B7 and H12 Clones. Proliferation and differentiation are reciprocally and tightly regulated [35]. Because A549 cells are derived from lung adenocarcinomas, it was generally thought that the cells reduced serum dependency and acquired the increase in autonomous growth. Thereby, we initially examined the effect of serum depletion on their proliferation (Figure 2(a)). Both B7 and H12 increased their cell numbers in the culture medium with serum until $72 \mathrm{~h}$. However, cell proliferation was suppressed from $48 \mathrm{~h}$ in the serum-free medium. After $72 \mathrm{~h}$, cell numbers started to decrease in both culture conditions. Next, we examined the effects of serum depletion on the gene expression of SPC, AQP5, and also hypoxiainducible factor-1 $\alpha$ (HIF-1 $\alpha$ ) which regulates the phenotypes of cancer cells including their progressive proliferation [3638] (Figures 2(b) and 2(c)). In B7, significant enhancement of $S P C$ expression was observed from $48 \mathrm{~h}$ by serum depletion compared with control (Figure 2(b)). At $120 \mathrm{~h}$, the expression level was upregulated 2.9-fold compared with that at time 0 . In contrast, $A Q P 5$ was induced significantly at $24 \mathrm{~h}$ and the expression level was maintained until $120 \mathrm{~h}$ by serum depletion. The expression level of HIF-1 $\alpha$ was not significantly altered.

On the other hand, in H12, SPC expression was enhanced from $24 \mathrm{~h}$ by the serum depletion when compared to the control (Figure 2(c)). The maximum expression level was observed at $72 \mathrm{~h}$ as a 1.7 -fold increase compared with that at time 0. However, in contrast to B7, the expression level started to decrease from $96 \mathrm{~h}$ in conditions with or without serum. AQP5 expression was enhanced in a time-dependent manner by serum depletion, and the maximum expression level was 2.8 -fold at $120 \mathrm{~h}$ compared with that at time 0 . HIF$1 \alpha$ expression was not significantly altered. All of these results indicate that the response to serum depletion was different between $\mathrm{B} 7$ and $\mathrm{H} 12$.

3.3. Effects of EGF Treatment on Gene Expression in B7 and H12 Clones. Because serum contains growth factors and A549 cells have been reported to undergo EGFR amplification [29], we hypothesized that the effects of serum depletion could be because of the absence of EGF in the serum. To confirm this possibility, we cultured B7 and $\mathrm{H} 12$ in the serum-free medium with EGF (10, 30, and $90 \mathrm{ng} / \mathrm{mL})$. In B7, SPC expression was enhanced from $24 \mathrm{~h}$ by serum depletion (Figure 3(a)). Ten and $30 \mathrm{ng} / \mathrm{mL}$ of EGF treatment did not affect $S P C$ expression. A minor suppression of $S P C$ was observed by $90 \mathrm{ng} / \mathrm{mL}$ of EGF treatment. In contrast, AQP5 expression was induced from $24 \mathrm{~h}$ by serum depletion. By the addition of EGF, the induction of $A Q P 5$ was delayed in a dosedependent manner. In $\mathrm{H} 12$, the enhancement of both SPC and AQP5 expressions by serum depletion was not affected by EGF treatment (Figure 3(b)). These results indicated that EGF in serum-containing medium had little effect on the alveolus-specific gene expression.

3.4. Effects of MEK Inhibitors on Gene Expression in B7 and H12 Clones. A549 cells have been demonstrated to have the K-RAS mutation (G12S) and show activation of MAPK signaling $[27,28]$. To examine whether serum depletion effects could be replaced by inhibition of MAPK signaling, we treated B7 and H12 with U0126 and PD98059. We first confirmed the effects on cell proliferation of both clones treated with U0126 $(3,10$, and $30 \mu \mathrm{M})$ or PD98059 (30, 60 , and $90 \mu \mathrm{M}$ ), respectively (Figure $4(\mathrm{a})$ ). In both B7 and $\mathrm{H} 12$, cell proliferation was suppressed by both U0126 and PD98059 in a dose-dependent manner. The most effective dose was $30 \mu \mathrm{M}$ of $\mathrm{U} 0126$ and $90 \mu \mathrm{M}$ of PD98059. Although 


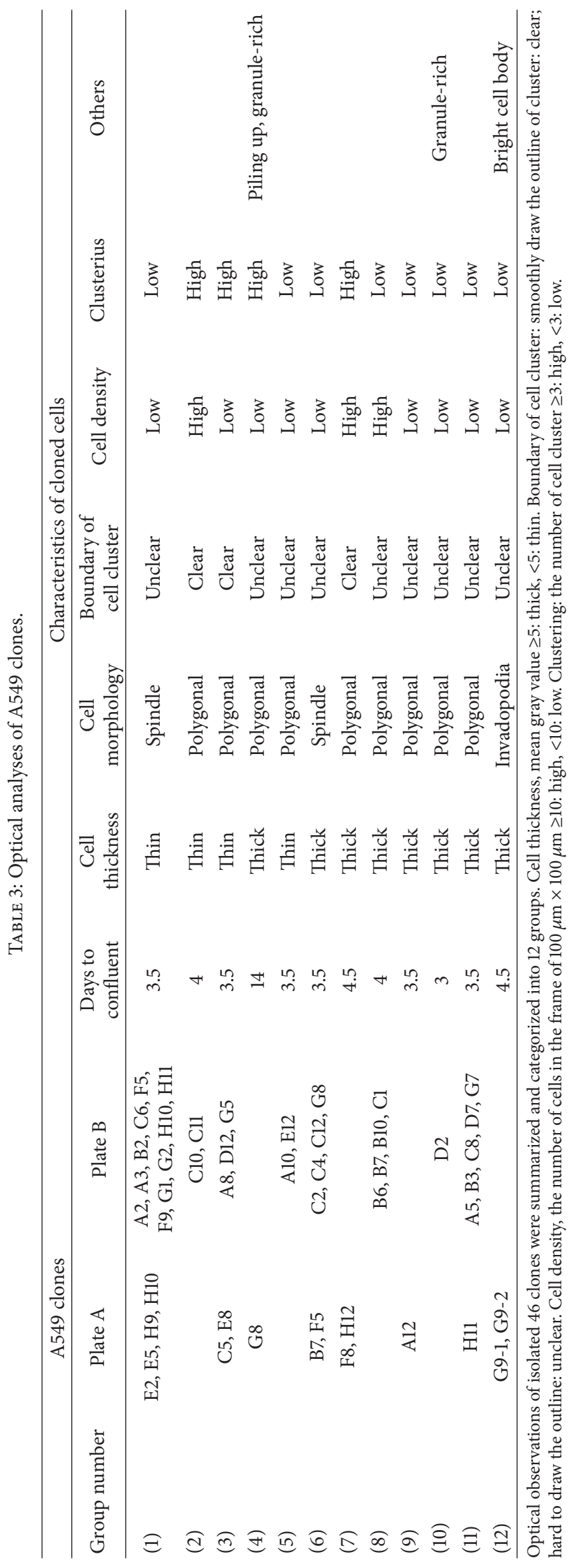




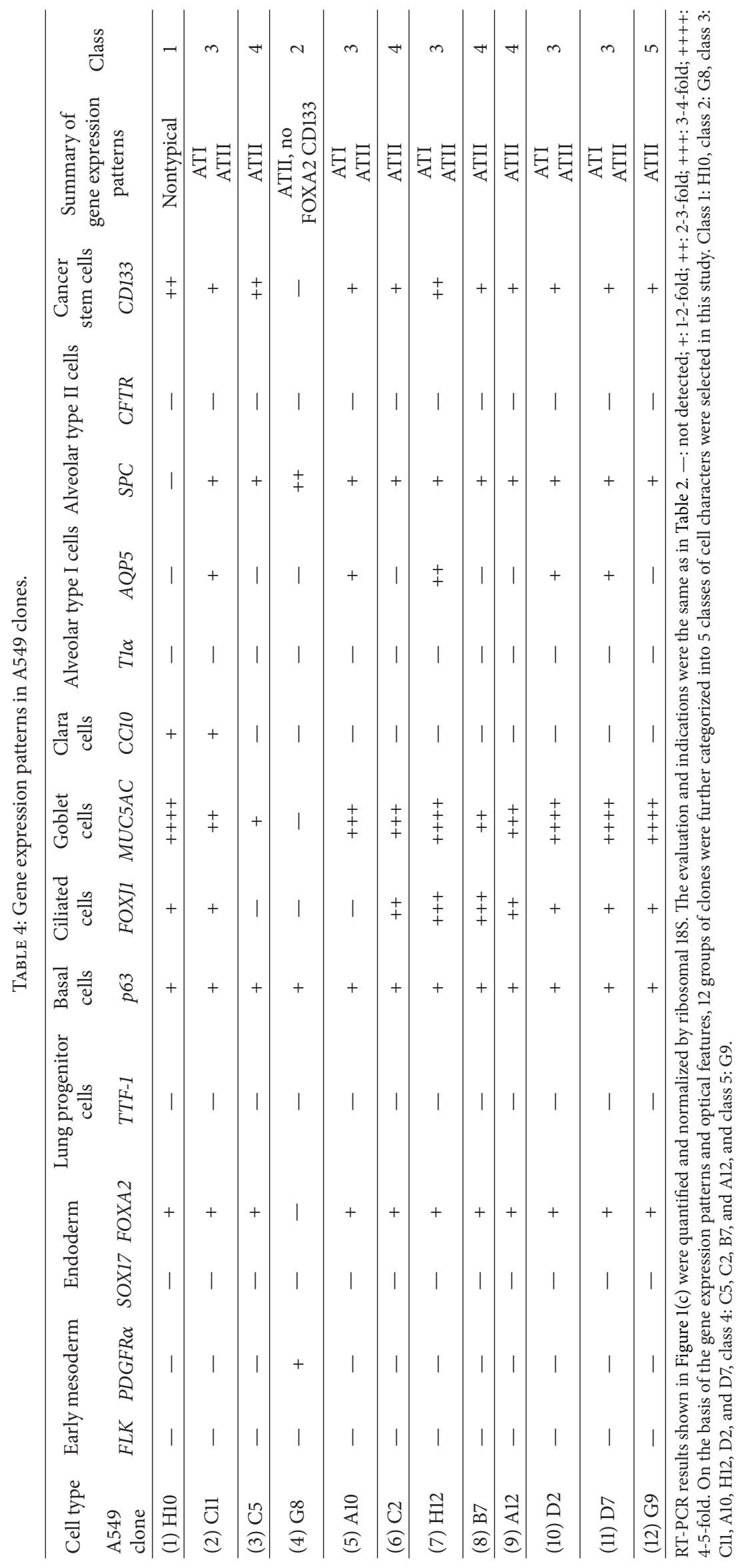



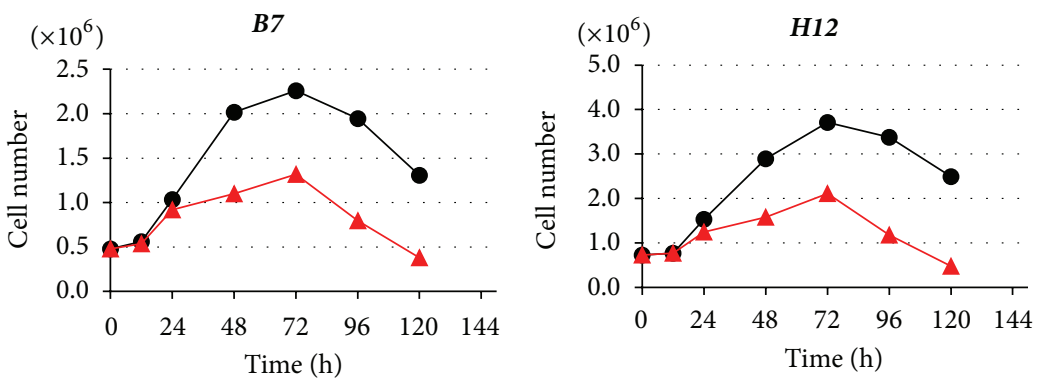

(a)

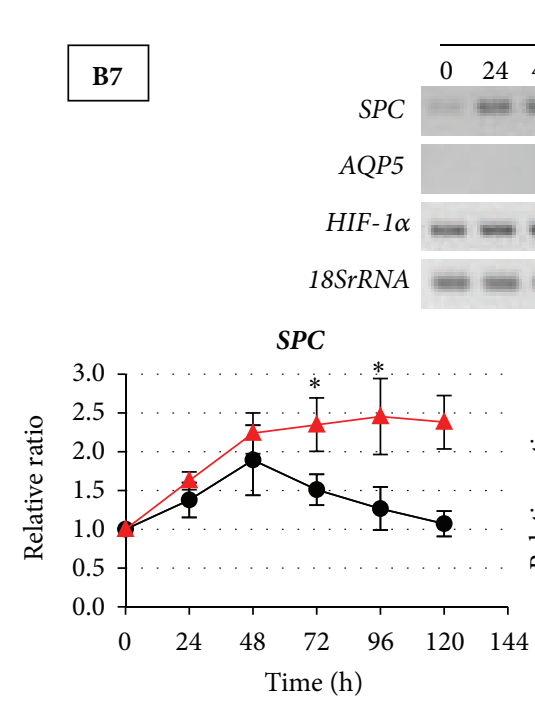

Serum

Serum-free

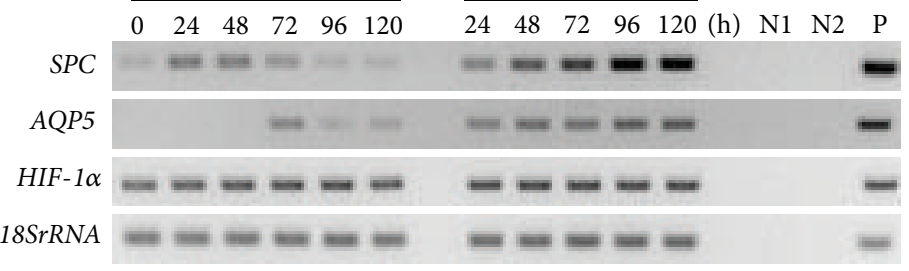

AQP5

HIF-1 $\alpha$
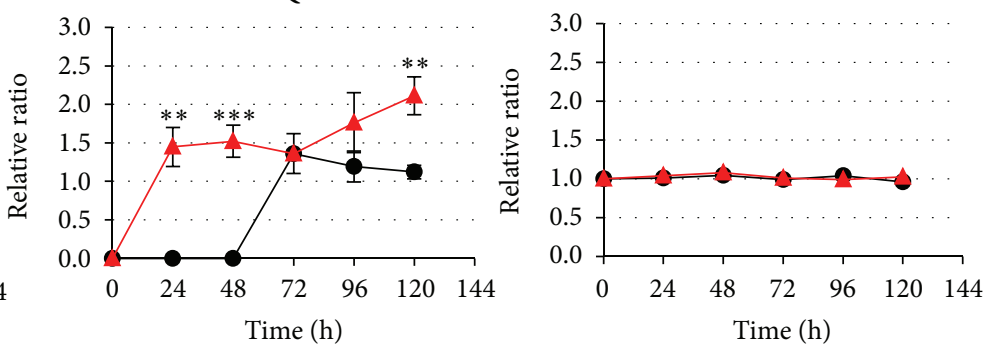

(b)
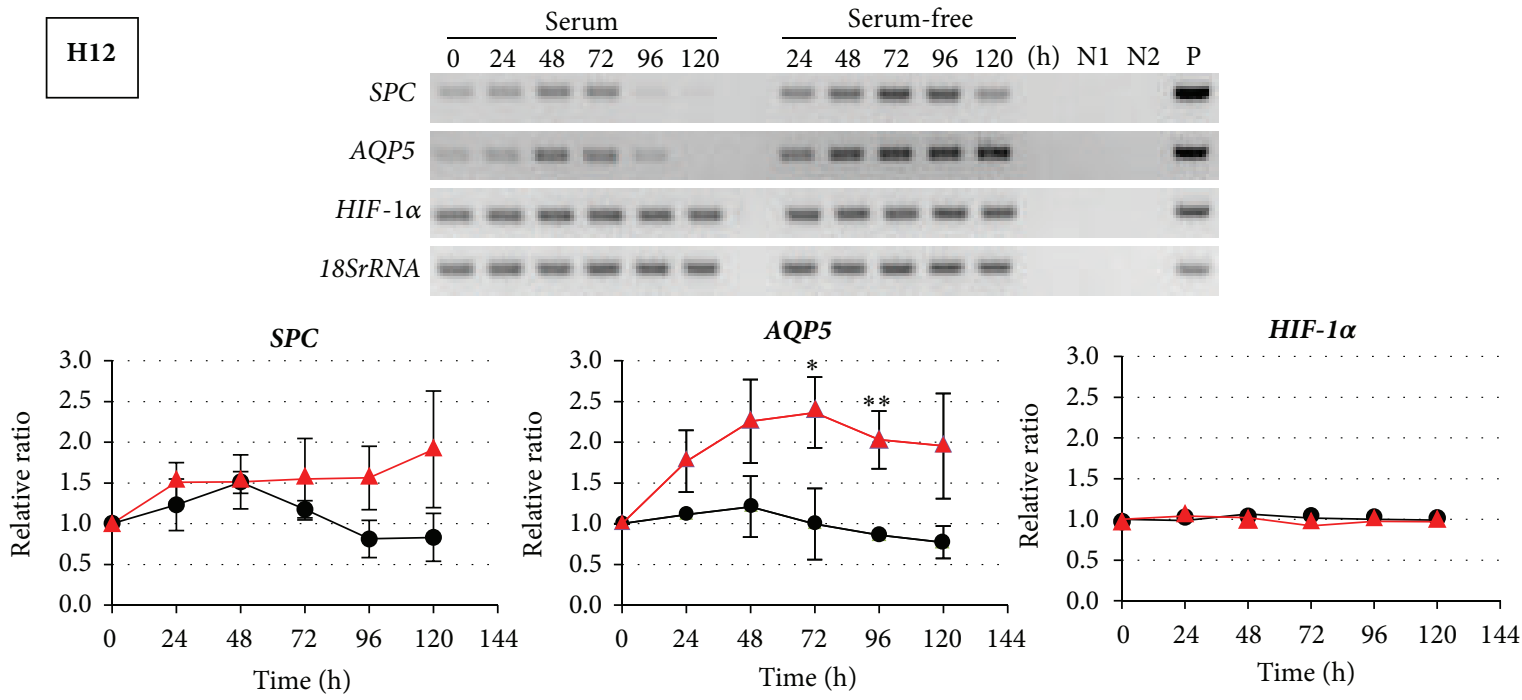

(c)

FIGURE 2: Effects of serum depletion on cell characteristics of A549 clones. (a) Growth curve of B7 (left) and H12 (right). Black: cultured with serum, red: cultured without serum. (b) and (c) Expression and quantitative analyses of SPC, AQP5, and HIF-1 $\alpha$ mRNA in B7 cells (b) and in H12 cells (c). (Upper panel) representative RT-PCR results. N1: negative control without RT reaction, N2: negative control with distilled water, and P: positive control with sequenced PCR products in plasmid. (Lower three panels) quantitative analysis of gene expression. Black: cultured with serum, red: cultured without serum. Experiments were independently performed in triplicate. ${ }^{*} p<0.05 ;{ }^{* *} p<0.01$; ${ }^{* * *} p<0.001$. 


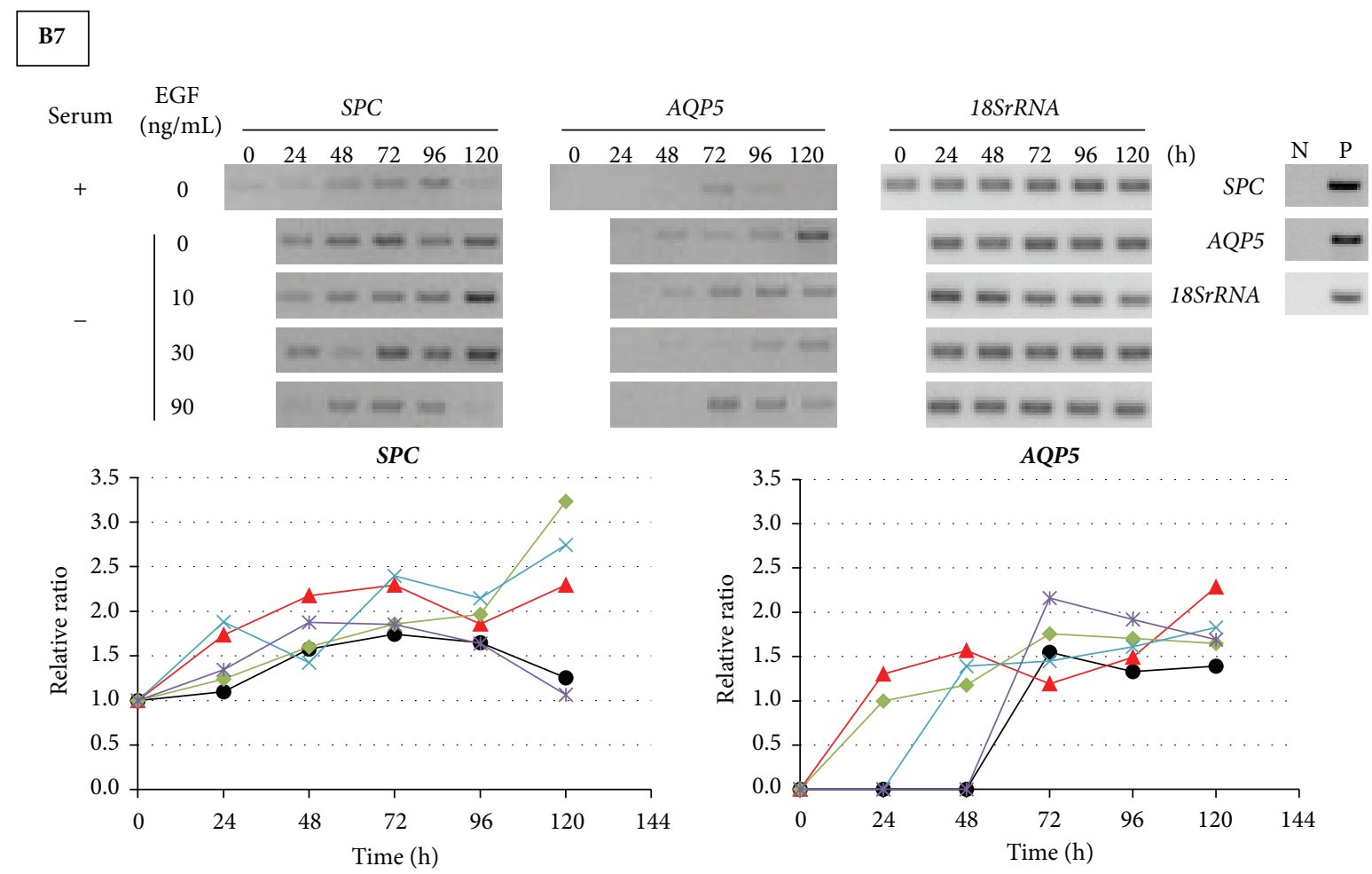

(a)

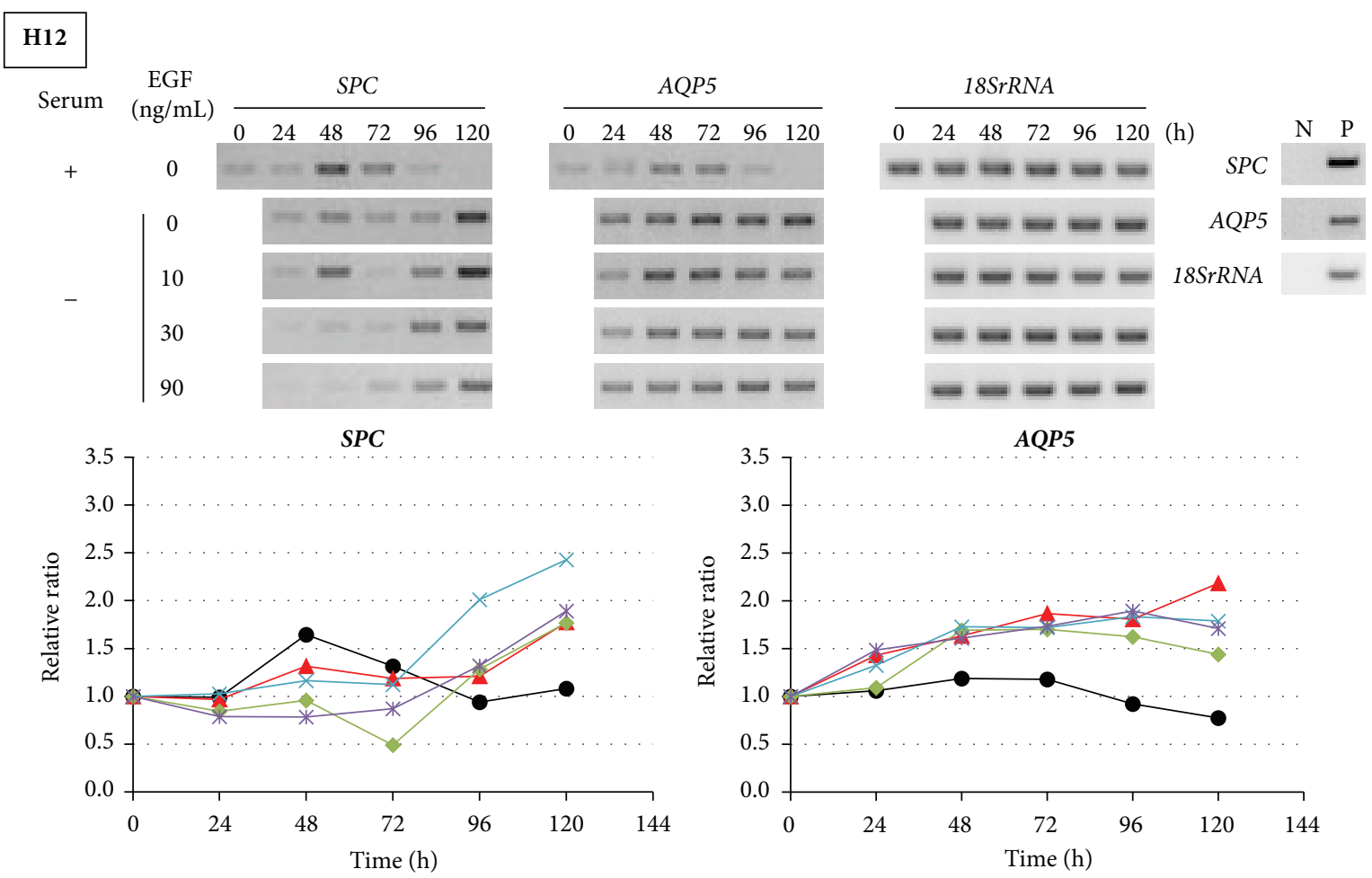

(b)

FIGURE 3: Effects of EGF treatment on gene expression in B7 and H12 clones. (a) and (b) Expression and quantitative analyses of SPC and AQP5 mRNA in (a) B7 and in (b) H12. (Upper panel) representative RT-PCR results. Serum +: cultured with serum, -: cultured without serum, N: negative control without RT reaction, and P: positive control. (Lower panel) quantitative analyses of gene expression. Black: serum, red: serum-free, green: serum-free + EGF $10 \mathrm{ng} / \mathrm{mL}$, light blue: serum free + EGF $30 \mathrm{ng} / \mathrm{mL}$, and purple: serum-free + EGF $90 \mathrm{ng} / \mathrm{mL}$. All data were independently obtained twice. 
these concentrations seemed to be relatively high compared to the dosages used in the previous studies to inhibit ERK phosphorylation (e.g., $10 \mu \mathrm{M}$ of U0126 and $25 \mu \mathrm{M}$ of PD98059 $[39,40])$, we did not observe increasing numbers of floating cells dependent on the culturing time (data not shown). When we harvested the attached cells, the morphology was the same as that of healthy cells, and the viability of collected cells was more than $90 \%$ (data not shown). Therefore, we assessed both concentrations of inhibitors were not toxic. A slight difference in growth response to MEK inhibitor was observed between B7 and H12. B7 was much more sensitive to both inhibitors than $\mathrm{H} 12$ and showed earlier suppression of cell proliferation than $\mathrm{H} 12$.

Next, we examined the effects of the MEK inhibitors on gene expression in B7 and H12. In B7, SPC expression was transiently upregulated 1.9 -fold at $24 \mathrm{~h}$ by $\mathrm{U} 0126$ treatment; however, it was decreased by PD98059 treatment when compared with the control (Figure 4(b)). Although TTF-1 expression was not detected by 30 cycles, it could be detected by 40 cycles. Under this PCR condition, TTF-1 expression was upregulated 1.2-fold after U0126 treatment and 1.1-fold after $24 \mathrm{~h}$ treatment with PD98059. At $48 \mathrm{~h}$, TTF-1 expression was decreased under all conditions except serum depletion. The effects of the MEK inhibitor on both AQP5 and $S P B$ expression were varied. On the other hand, in H12, SPC expression was transiently upregulated 1.7 -fold at $24 \mathrm{~h}$ after U0126 treatment, but not after PD98059 treatment (Figure 4(c)). TTF-1 expression was transiently upregulated 1.5 -fold at $24 \mathrm{~h}$ after U0126 treatment and 1.4-fold after PD98059 treatment. Expression levels of AQP5 and SPB were not altered by U0126 and PD98059 treatment.

3.5. Effects of DCIK Treatment on B7 and H12 Clones. Previous studies reported that TTF- 1 can promote $S P C$ and $S P B$ expression [18-20]. Although SPC and TTF-1 expression was enhanced after U0126 treatment was transiently observed in some cases, it was not reproducible in our experiments. Recently, DCIK treatment has been reported to promote differentiation of progenitor cells induced from mouse ESCs and human iPSCs into ATII cells [41, 42]. Furthermore, the tissue-derived ATII cells could maintain their characteristics in vitro with DCI treatment $[43,44]$; in addition, following DCI removal, they could enhance the expression for ATI cell markers [45]. To test whether A549 clones respond to the culture conditions with DCIK, we next examined the effects of DCIK addition on the expression of ATII cell marker genes, following MEK inhibitor treatment. As shown in Figure 5(a), we first cultured B7 and $\mathrm{H} 12$ cells at 70\% confluence with $30 \mu \mathrm{M}$ of U0126 for $24 \mathrm{~h}$. After that, we changed the medium without DCIK (DCIK control) or with DCIK (DCIK) in the serum-free medium and continued to culture for $72 \mathrm{~h}$ (total culture time was $96 \mathrm{~h}$ ). After DCIK treatment, we exchanged the culture medium to remove DCIK and cultured with serum (DCIK + serum) or without serum (DCIK + serum free) for $72 \mathrm{~h}$. The morphology of $\mathrm{B} 7$ was significantly changed by DCIK treatment (Figure 5(b)). The shape of B7 became flat and spindle-like after $48 \mathrm{~h}$, and the outline of cell border became clearer. These elongated cells increased in a time-dependent manner, but the clear outline of cells was maintained at the similar level during the entire culture period.

We next examined the effects of combined treatment with MEK inhibitor and DCIK on the gene expression in B7 (Figure 5(c)). When compared with time 0, SPC expression was enhanced during U0126 treatment until $24 \mathrm{~h}$. After DCIK addition, SPC expression was decreased by $48 \mathrm{~h}$ and then increased in a time-dependent manner until $96 \mathrm{~h}$. However, these changes were observed in the same manner in the DCIK control. In contrast, at $72 \mathrm{~h}, A Q P 5$ was suppressed 0.5 -fold in DCIK, when compared with the DCIK control. TTF-1 expression was significantly increased up to 1.6-fold after DCIK treatment when compared with the DCIK control. $S P B$ was also enhanced in a time-dependent manner from $48 \mathrm{~h}$ and reached a 2.1-fold upregulation at $96 \mathrm{~h}$. After DCIK removal, SPC expression was decreased by $120 \mathrm{~h}$ and then increased in medium with and without serum in a timedependent manner. AQP5 was expressed only under serumfree conditions. However, TTF-1 and SPB expression levels were decreased by DCIK removal.

We also performed the same experiments with H12. Morphological changes were not observed in $\mathrm{H} 12$ after DCIK treatment (Figure 5(d)), but cells were more clustered after $48 \mathrm{~h}$. We next examined the effects of combined MEK inhibitor-DCIK treatment on the gene expression in H12 (Figure 5(e)). SPC expression was enhanced during U0126 treatment until $24 \mathrm{~h}$. After DCIK addition, SPC expression was decreased by $48 \mathrm{~h}$ and then increased in a timedependent manner until $96 \mathrm{~h}$. AQP5 was suppressed in DCIK at $48 \mathrm{~h}$ and remained at 0.7 -fold after $72 \mathrm{~h}$. TTF-1 expression was upregulated 1.3-fold at $48 \mathrm{~h}$ and remained at that level until $96 \mathrm{~h}$. $S P B$ expression was significantly increased by $48 \mathrm{~h}$ showing, up to 4.6 -fold upregulation at $72 \mathrm{~h}$ and remaining at that level until $96 \mathrm{~h}$. After DCIK removal, SPC expression was decreased by $120 \mathrm{~h}$ and then increased in medium with and without serum in a time-dependent manner. $A Q P 5$ was increased in a time-dependent manner in serum-free culture medium. TTF-1 decreased transiently at $120 \mathrm{~h}$ but recovered to the original expression level. SPB decreased but SPC increased in a time-dependent manner after DCIK removal.

\section{Discussion}

In this study, we tried to establish a simple and reproducible in vitro system that can be used to analyze the molecular mechanisms of lung alveolar epithelial cell differentiation. We isolated A549 clones and characterized them by phenotypic screening using their morphology and gene expression patterns of markers (Tables 2-4). According to the major expression patterns of alveolar cell markers [30,46], two A549 clones, B7 and H12, were further analyzed as tentative representatives for ATII and ATI/II cells.

We examined whether these clones showed any responses to the differentiation stimuli by inducing several culture conditions with or without serum, DCIK, and MAPK inhibitors. Both B7 and H12 had unique responses to those stimuli, reflecting the characteristics of ATII and ATI/II cells, and these responses were stably and reproducibly observed until passage 122 and passage 120, respectively (data not shown). 
B7

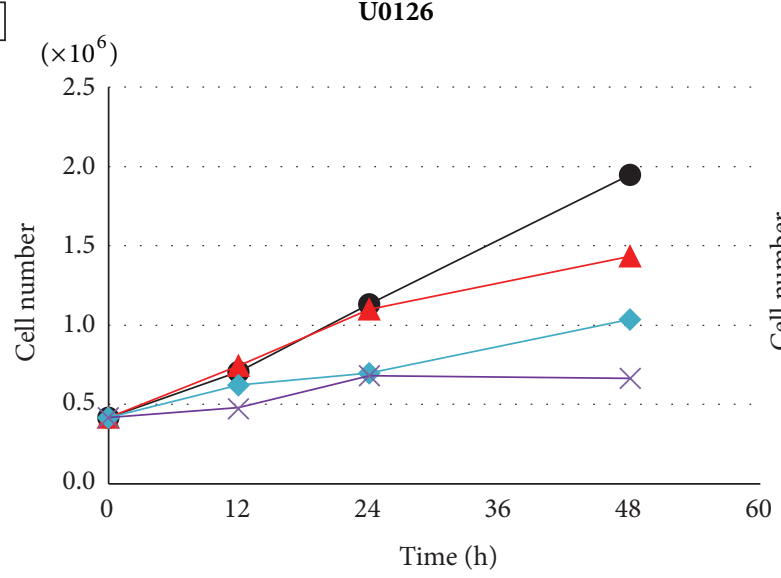

H12

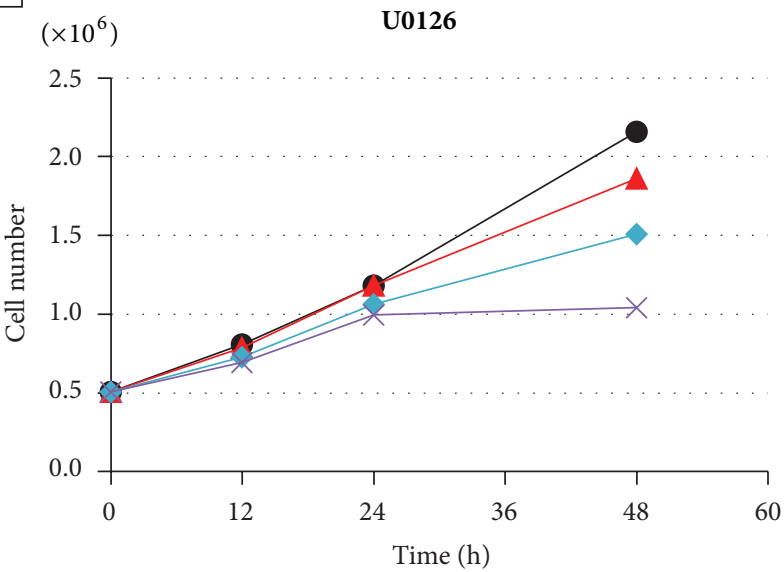

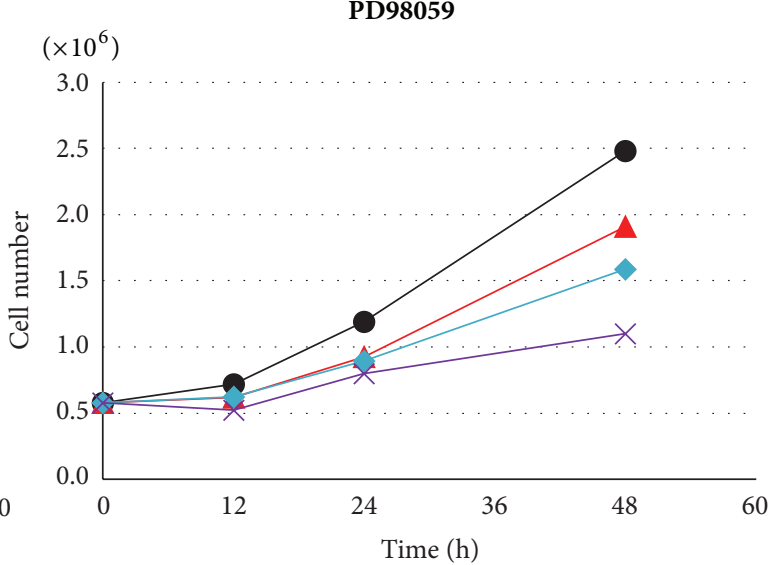

$\left(\times 10^{6}\right) \quad$ PD98059

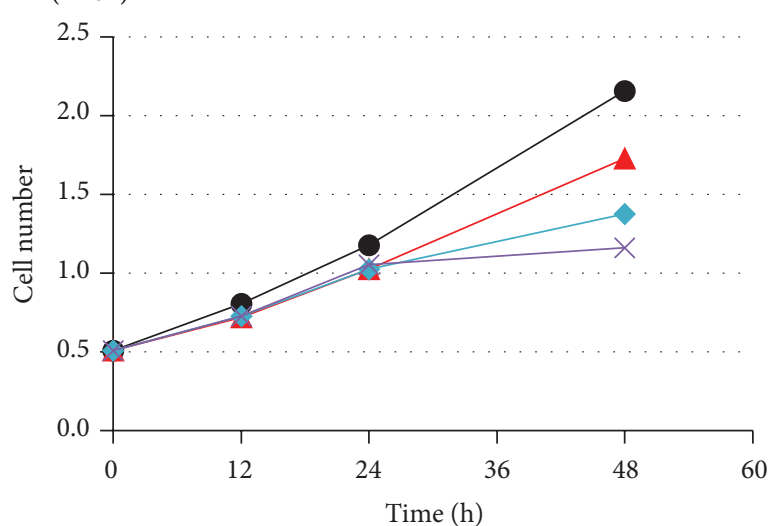

(a)

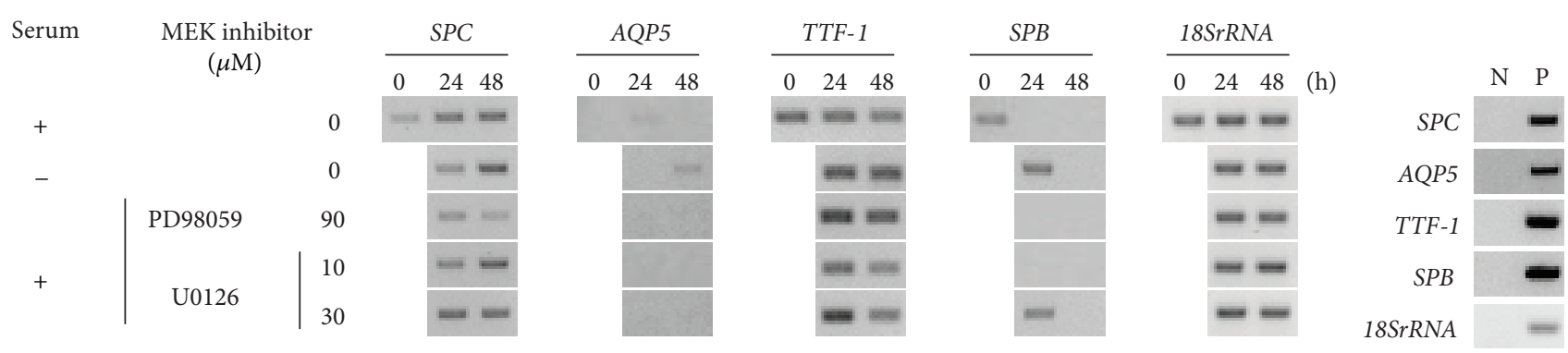
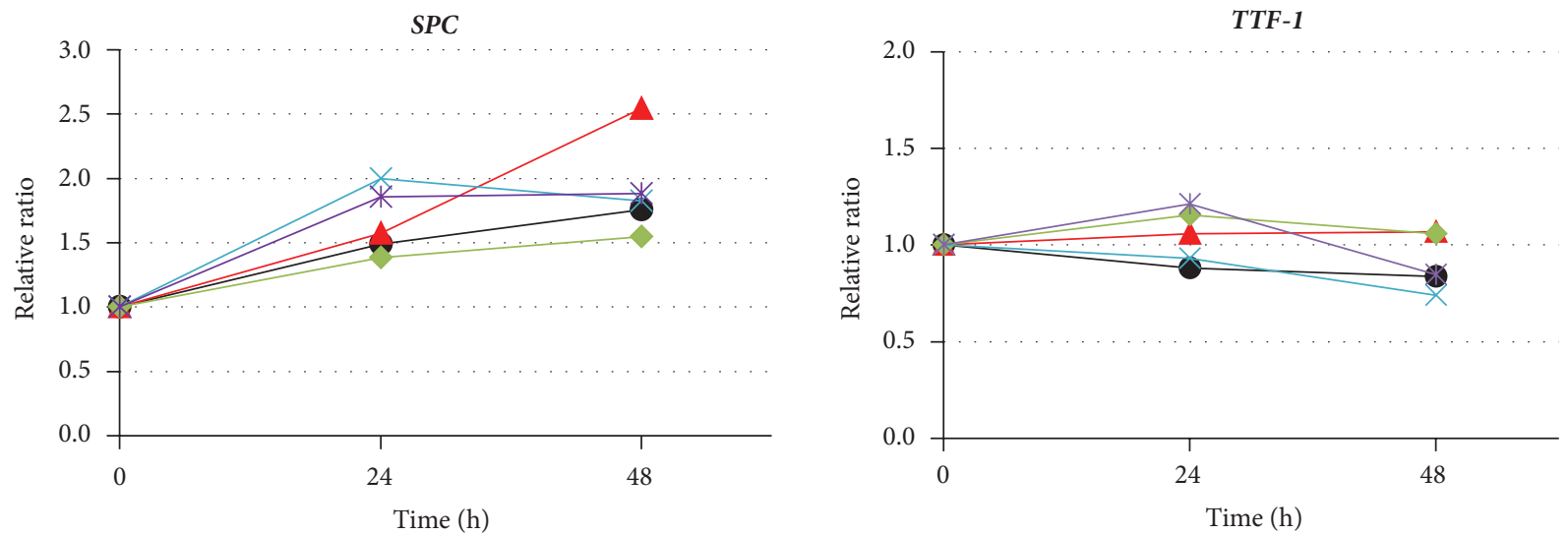

(b)

Figure 4: Continued. 

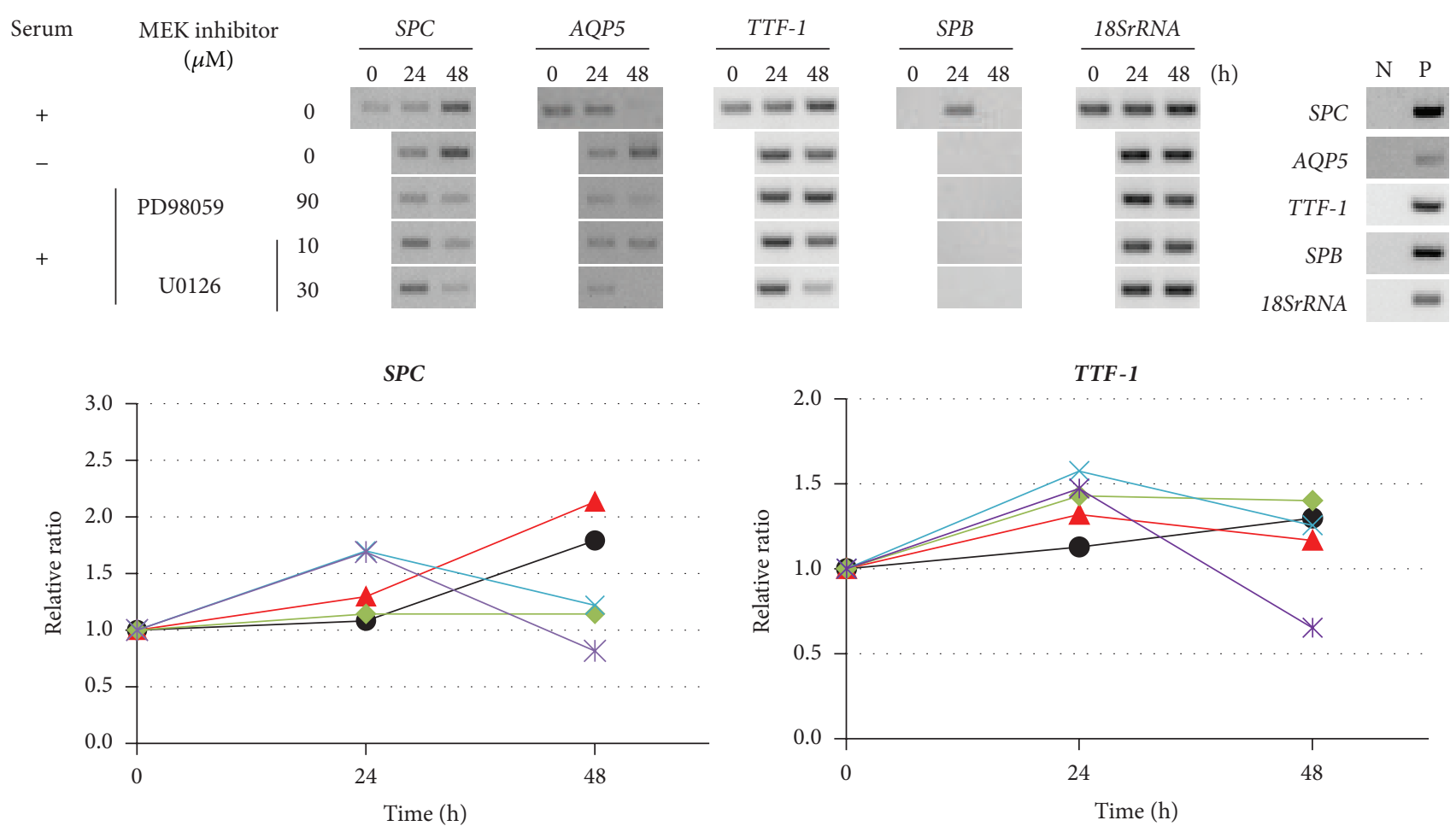

(c)

FIGURE 4: Effects of MEK inhibitors on gene expression in B7 and H12 clones. (a) Growth curve of B7 and H12 in serum-present medium treated with U0126 and PD98059, respectively. U0126 were treated with $3 \mu \mathrm{M}$ (red), $10 \mu \mathrm{M}$ (light blue), and $30 \mu \mathrm{M}$ (purple), and PD98059 were treated with $30 \mu \mathrm{M}$ (red), $60 \mu \mathrm{M}$ (light blue), and $90 \mu \mathrm{M}$ (purple) for the indicated time. Black indicted no treatment with MEK inhibitors. (b) and (c) mRNA expression and quantitative analysis of SPC, AQP5, TTF-1, and SPB by RT-PCR in B7 (b) and in H12 (c). Each data was independently obtained twice. (Upper panel) representative RT-PCR results. N: negative control, P: positive control. (Lower panel) quantitative analyses of gene expression. Black: cultured with serum, red: cultured without serum, green: PD98059 $90 \mu \mathrm{M}$, light blue: U0126 $10 \mu \mathrm{M}$, and purple: $\mathrm{U} 012630 \mu \mathrm{M}$.

The finding that serum-free condition could induce the gene expression of alveolar epithelial differentiation markers in A549 clones is consistent with those of the previous study [47].

Since cell growth and differentiation are reciprocally and tightly regulated [35], we characterized the growth rate with and without serum. We observed that A549 cells were highly proliferative in medium with serum, but serum depletion decreased the growth rate and reciprocally increased the expression of differentiation marker genes. In addition, both SPC and AQP5 proteins were not detectable by western blot analyses in serum depletion system (data not shown). Therefore, the cells can be primed but not fully differentiated in the present condition, suggesting that additional signals or environmental condition might be required to induce the protein expression.

Because K-RAS mutation (G12S) and EGFR amplification were detected in A549 cells, the effects of serum depletion were first considered to be related to the MAPK signaling cascade which is also known to play an important role in proliferation of cancer [48]. We found that the proliferation of A549 clones could be suppressed by the MEK inhibitor U0126 and showed an enhancement in the expression of the differentiation markers, SPC and TTF-1 (Figure 4). U0126, a MEK1/2 inhibitor [49], caused an enhancement in the SPC expression up to $24 \mathrm{~h}$ and then caused a reduction or maintenance up to $48 \mathrm{~h}$; however, it did not affect $A Q P 5$ expression. PD98059, a MEK1 inhibitor [50], did not affect either SPC or AQP5 expression. This suggests that RASMAPK signals might control the switch between proliferation and differentiation in A549 clones. The differential effects of these inhibitors on marker gene expression might be because of different target molecules, but this remains to be determined.

Second, serum contains a variety of factors, including growth factors such as EGF. Lauand et al. demonstrated that A549 cells amplified EGFR without phosphorylation, and EGF stimulation could activate actin filament organization and cell motility rather than inducing proliferation in A549 cells [51]. However, we observed that EGF had little effect on the expression of differentiation markers (Figure 3 ). Therefore, it is possible that other ligands in serum, such as tumor necrosis factor- $\alpha$, amphiregulin, and heparinbinding EGF-like growth factor [52-55] could activate EGFRmediated signals. Further analysis is required to determine 


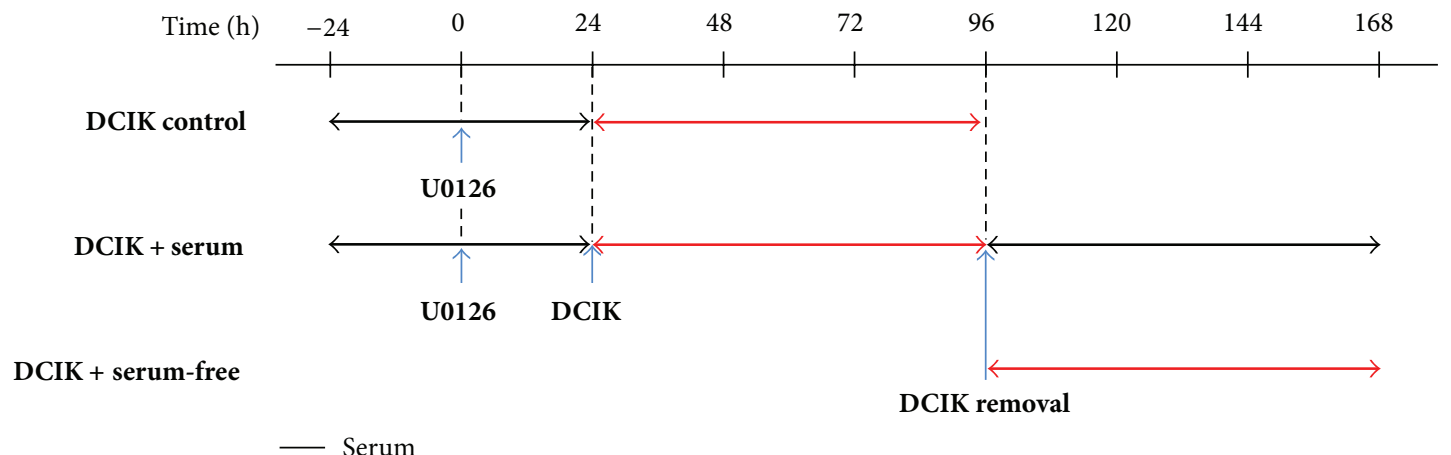

— Serum
_ Serum-free

(a)

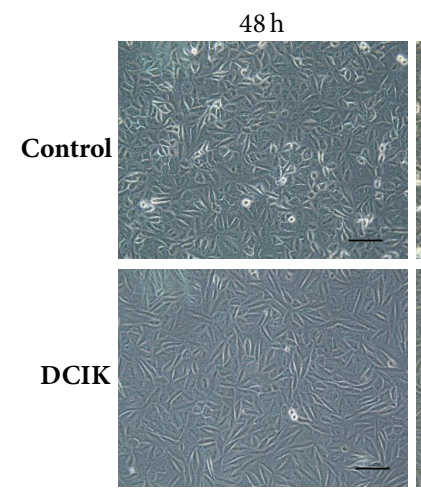

$72 \mathrm{~h}$
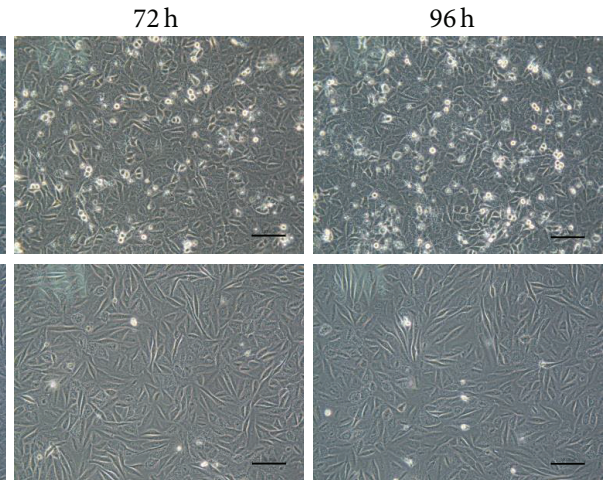

(b)

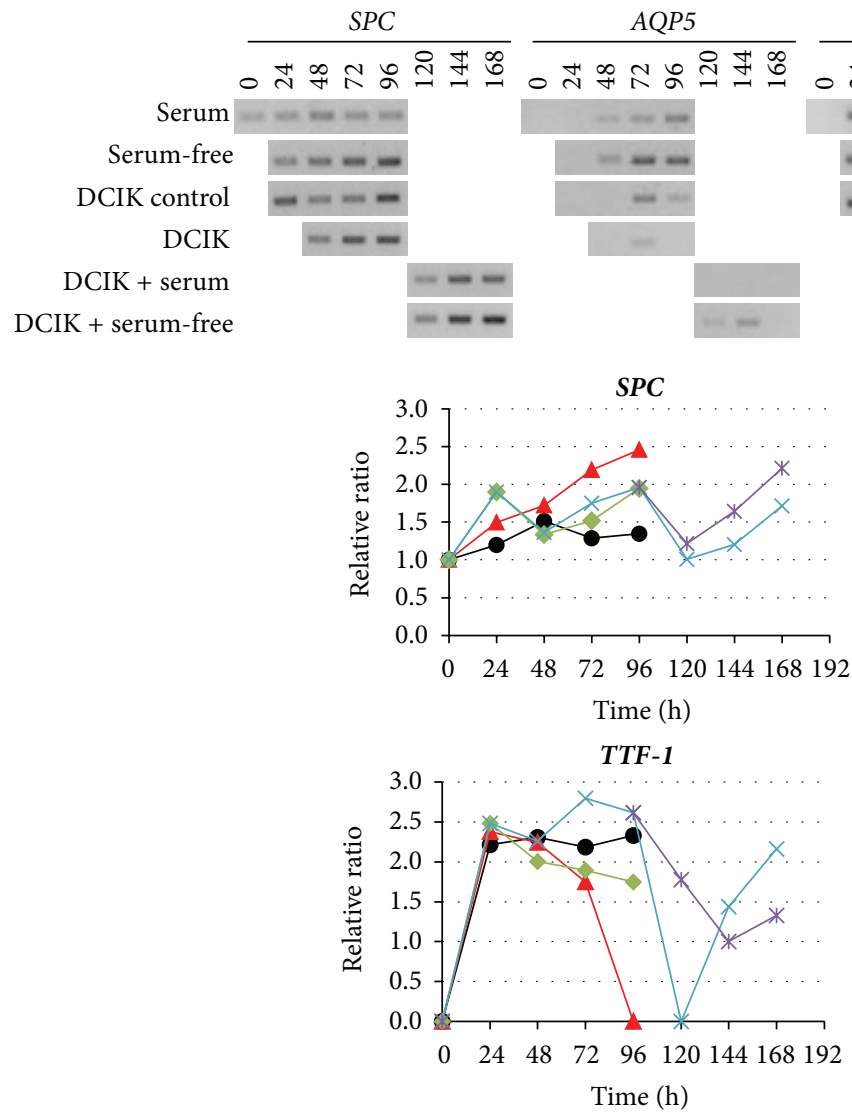

TTF-1

$S P B$

18SrRNA
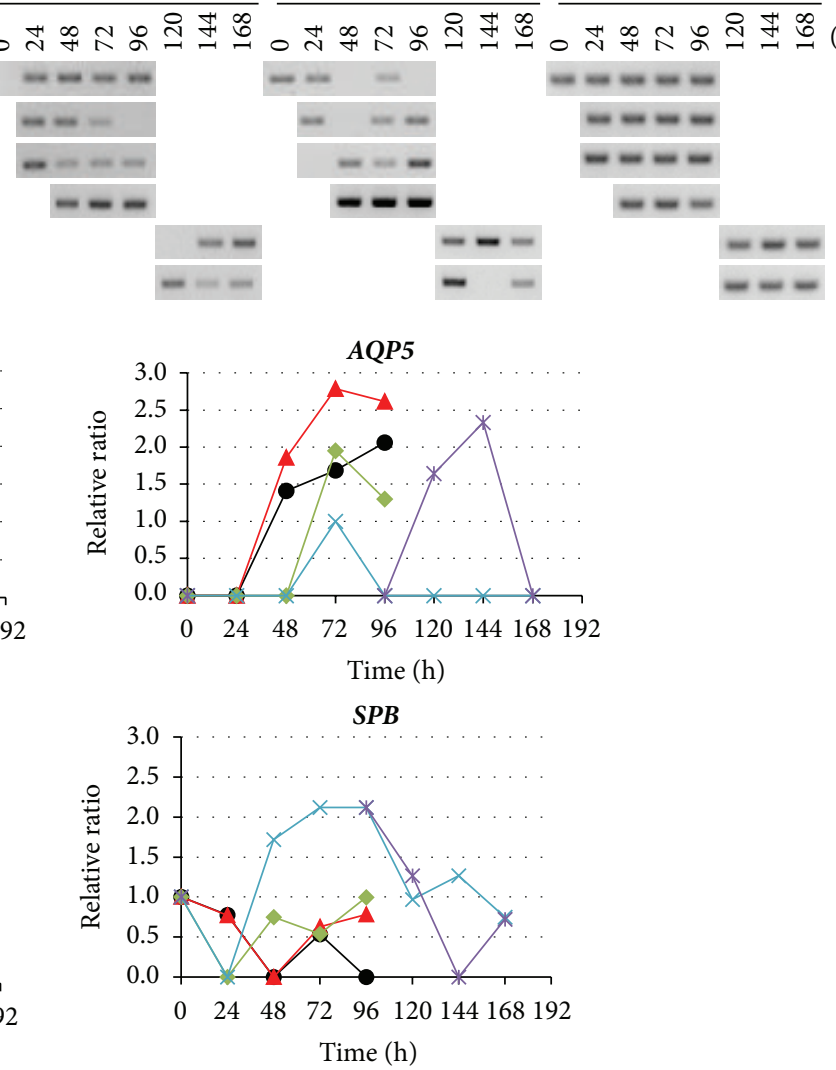

(c)

Figure 5: Continued. 

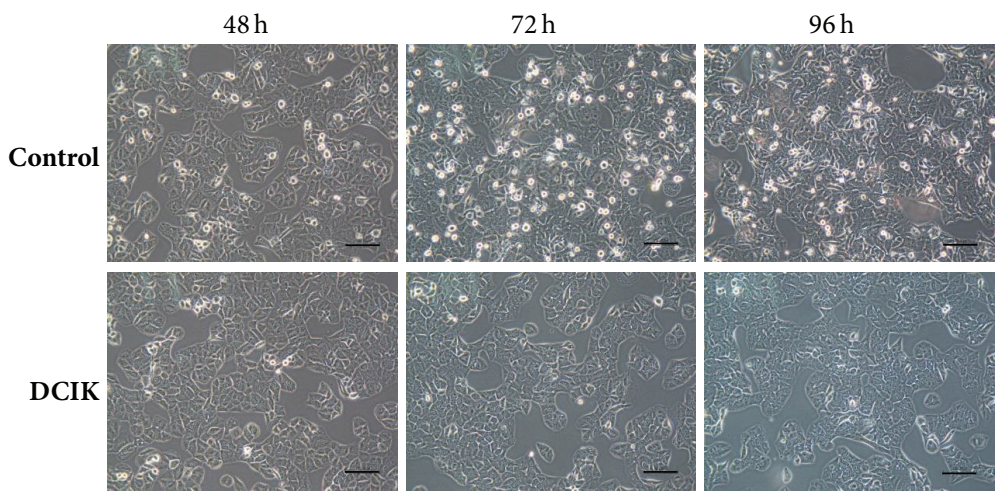

(d)
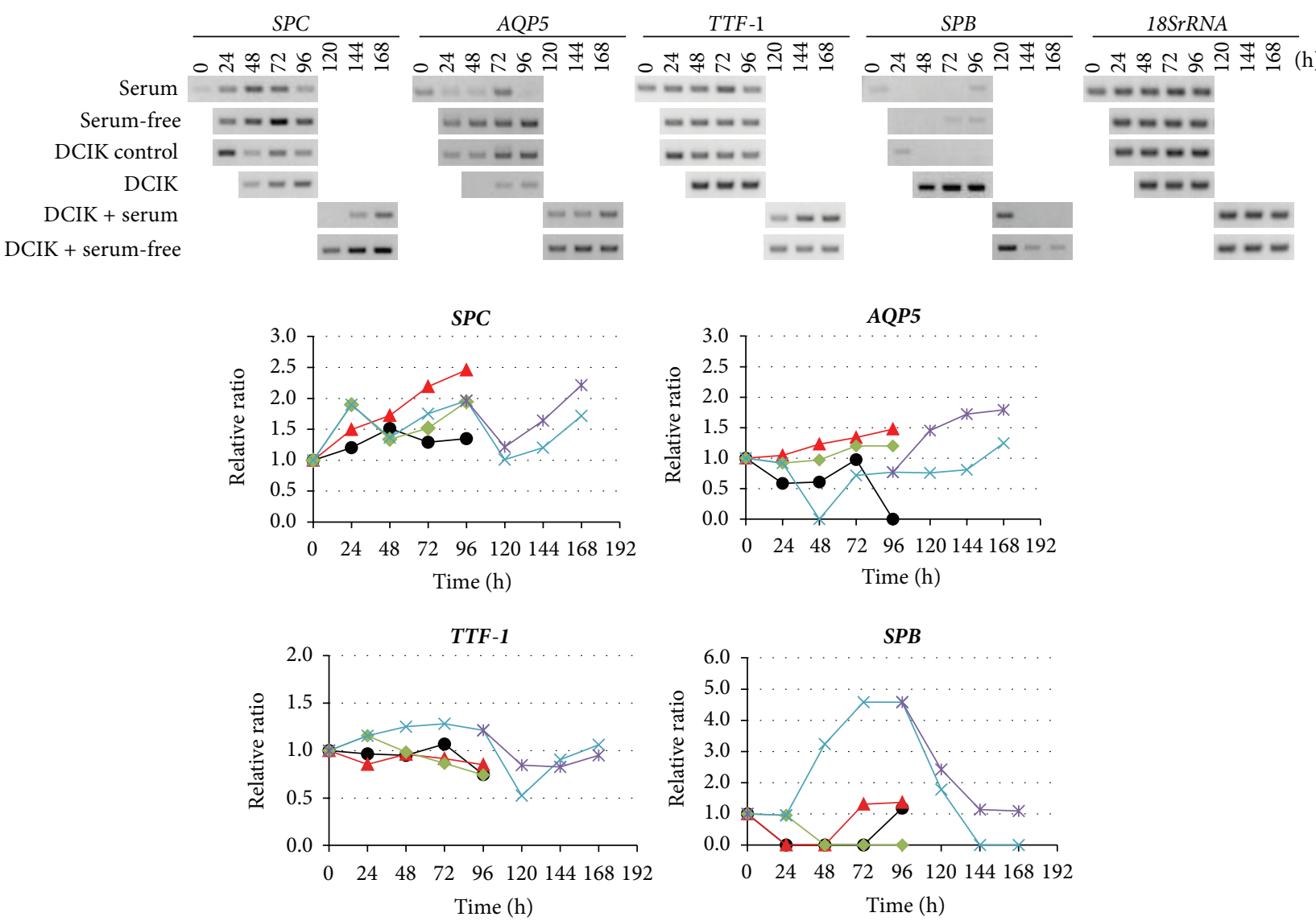

(e)

FIGURE 5: Effects of DCIK treatment following U0126 treatment. (a) Experimental design. B7 and H12 were treated with DCIK for 3 days following U0126 $30 \mu \mathrm{M}$ treatment for $24 \mathrm{~h}$. After DCIK removal, B7 and H12 were cultured with serum or without serum for 3 days. (b) Morphological change of B7 treated without DCIK (control) and with DCIK (DCIK) at every 24 h for 3 days following U0126 treatment for $24 \mathrm{~h}$. Scale bar: $100 \mu \mathrm{m}$. (c) Expression and quantitative analysis of SPC, AQP5, TTF-1, and SPB mRNAs in B7. (Upper panel) RT-PCR results. (Lower four panels) quantitative analyses of gene expression. Black: cultured with serum, red: cultured without serum, green: cultured without DCIK following U0126 treatment for $24 \mathrm{~h}$, light blue: cultured with DCIK following U0126 treatment for $24 \mathrm{~h}$ and cultured with serum following DCIK treatment, and purple: cultured without serum following DCIK treatment. (d) Morphological change of H12 treated without DCIK (control) and with DCIK (DCIK) at every $24 \mathrm{~h}$ for 3 days following U0126 treatment for $24 \mathrm{~h}$. Scale bar: $100 \mu \mathrm{m}$. (e) Expression and quantitative analysis of $S P C, A Q P 5, T T F-1$, and $S P B$ mRNAs in H12. (Upper panel) RT-PCR results. (Lower four panels) quantitative analyses of gene expression. Indications were the same as in (c). All data were independently obtained twice. 
the mechanism of the enhancement in differentiation marker gene expression under serum-free condition.

To induce cell differentiation, the control of energy metabolism is another important issue to be discussed. The energy metabolism in A549 cells is regulated by the Warburg effect [56]. Aerobic glycolysis is dominant and mitochondrial oxidative phosphorylation is decreased. The switch in energy metabolism from glycolysis to mitochondrial oxidative phosphorylation has been demonstrated to induce differentiation in cancer cells [57]. That prompted us to examine the effects of glycolysis and/or pyruvate dehydrogenase kinase- (PDK-) inhibitors to increase the flow of carbon metabolites into tricarboxylic acid cycle and switch the differentiation cue. We examined the effects of glycolysis by culture in the specific medium (depleted with L-glutamine, glucose, and sodium pyruvate), the inhibitors of both pyruvate dehydrogenase kinase and lactate dehydrogenase combined with U0126 on the gene expression levels of differentiation markers. However, we did not detect any induction or enhancement in gene expression as a result of these treatments (data not shown), suggesting that in our experimental condition, at least in part, glucose metabolism did not have a major role in the A549 clones.

Recently, several reports have studied the suitable culture conditions to maintain ATII function and induce ATI differentiation [41-45]. DCI treatment in vitro could maintain and enhance ATII characteristics of natural ATII cells isolated from lung in human fetuses and adults $[43,44]$. Furthermore, KGF treatment could increase surfactant protein gene expression and decrease AQP5 expression [58-60]. Using mouse ESCs and human iPSCs, it has also been reported that KGF combined with DCI treatment leads to the maturation of ATII-like cells from the progenitor cells [41, 42, 61]. Since mouse epiblast stem cells and human iPSCs have been shown to have a similar energy metabolism to cancer cells [62], we used the combination of U0126 and DCIK to suppress cell proliferation and examined the cell morphology and gene expression of alveolar differentiation markers (Figure 5). This treatment induced a morphological change (flat and spindle shape) in B7, and increased cell-clustering in $\mathrm{H} 12$, respectively. SPC was not significantly increased by DCIK treatment, but $S P B$ and $T T F-1$ were significantly enhanced. AQP5 expression, however, was decreased in both clones. These findings suggested that the expression of ATII-marker genes was enhanced by DCIK treatment. The morphological change in B7 which we observed was slightly similar to the epithelial mesenchymal transition; however, epithelial markers $S P B$ and $S P C$ were detected. Further analysis is required for better understanding the meaning of morphological change induced by DCIK treatment. In addition, ATII-like cells could be differentiated from the isolated ATII cells of human fetal lung, which were maintained in a DCIadded medium, into ATI-like cells, by the removal of DCI [45]. In our system using A549 clones, DCIK removal did not affect either AQP5 or SPC expression but decreased $S P B$ expression. These data suggest that A549 clones require the additional cues for ATI induction.
For the in vivo events following lung injury, ATII cells proliferate and spread, and their daughter cells could differentiate into ATI cells [21-24]. An in vitro study demonstrated that siRNA of transforming growth factor- $\beta$ (TGF- $\beta$ ) and recombinant human bone morphogenetic protein- (rhBMP-) 4 could upregulate expression of ATII markers, whereas siRNA of BMP receptors and rhTGF- $\beta$ upregulated expression of ATI markers in mouse ATII cells [63]. Additionally, ATII cells treated with insulin-like growth factor-I (IGF-I) differentiate into ATI-like cells by activation of Wnt5a in rat ATII cells [64]. These findings indicated that cytokine signals might play the key roles in both genetic and epigenetic programs during lung development.

Finally, we obtained an interesting finding about genetic background of B7 and $\mathrm{H} 12$ clones by analyzing the cell authentication. Both B7 and H12 maintain A549 signature, except Y chromosome-loss in $\mathrm{H} 12$ (data not shown). Y chromosome instability has been reported in some of human cancer, and it is thought that $\mathrm{Y}$ chromosome loss or gain is related with progression of malignancy [65]. However, the biological meaning of $\mathrm{Y}$ chromosome instability in tumor progression is still unclear. Interestingly, the introduction of $\mathrm{Y}$ chromosome into the human prostate cancer cell line, PC-3, suppressed tumor formation [66], and loss of Yp11.2 containing TSPY gene shows strong correlation with tumorigenesis in prostate cancer [67]. And a recent study reported the loss of Y chromosome in the elderly peripheral blood is associated with shorter cancer survival and higher risk of cancer incidence [68]. Since tumor cells have plasticity and phenotypic heterogeneity [69], Y chromosome-loss can be a cause of the phenotypic difference between B7 and H12. Further detailed analyses of Y chromosome-loss, epigenetic status, and transcriptome analysis in $\mathrm{H} 12$ are required for better understanding the characteristics of the clone $\mathrm{H} 12$ and the mechanism of alveolar differentiation.

Taken together, we summarized our findings in Figure 6 as an in vitro A549 model compared with an in vivo model that has been recently reported [25]. During lung alveolar development, the bipotent progenitor cells differentiate into ATI and ATII cells. When alveoli are injured or damaged in adult, ATII cells can differentiate into ATI cells and maintain the supply of ATII cells by self-renewal to keep alveolar homeostasis and restore the tissue defects [21-26]. However, when ATII cells acquired a K-RAS mutation and/or EGFR mutation, they could be transformed into cancer cells [70, 71].

In an A549 model, A549 has been demonstrated to have K-RAS mutation (G12S) and EGFR amplification [27-29] and lose some of the characteristics of ATII cells [31, 32]. In our study, we found that A549 clone B7 has characteristics of ATII cells, and H12 has characteristics of both ATI and ATII cells based on the expression of differentiation marker genes. We also observed that ATII-like characteristics could be enhanced or recovered, in both $\mathrm{B} 7$ and H12, under the culture condition with U0126 followed by DCIK treatment. Further analyses are required to understand the detailed regulatory mechanisms of ATI and ATII marker gene expression and find out further effective differentiation system using these clones. Our findings suggested that A549 clones would provide a simple and easy in vitro model system as 


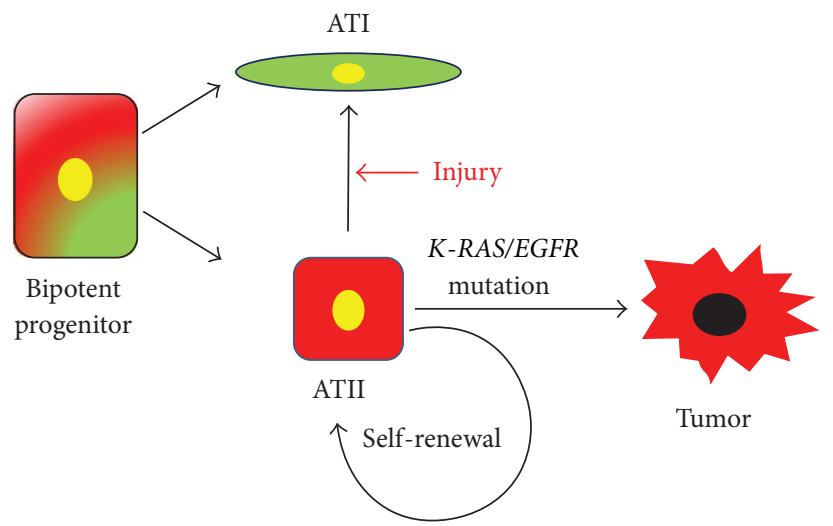

In vitro A549 model

(a)

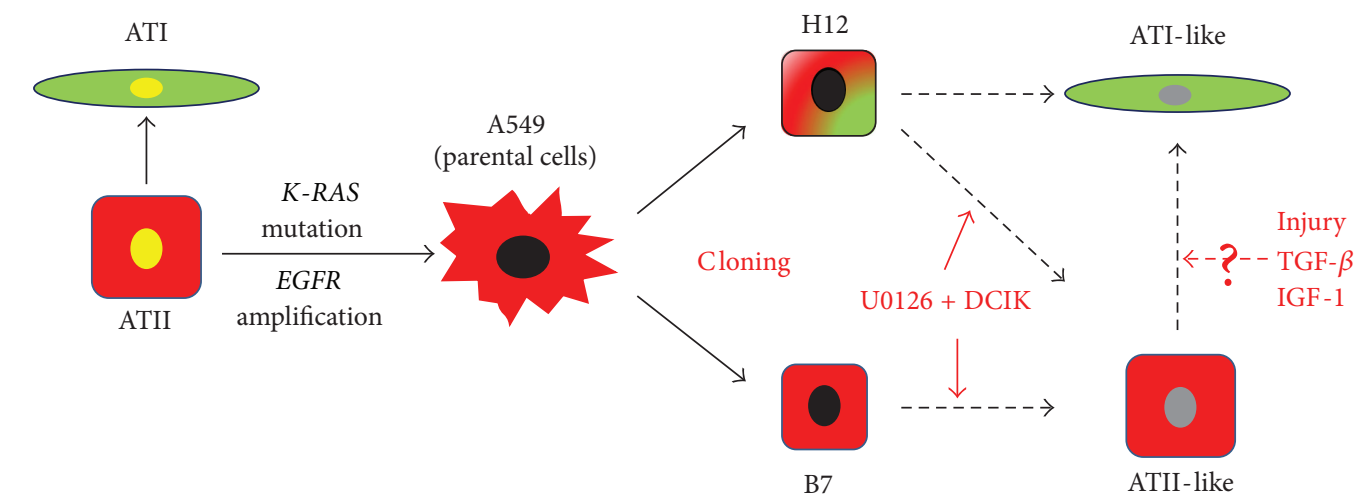

(b)

Figure 6: In vivo lung alveoli and in vitro A549 model. (a) In vivo model. Bipotent progenitor cells differentiate into ATI cells and ATII cells. ATII cells have stem cell-like functions, which are able to differentiate into ATI cells by injury and to maintain themselves by self-renewal. When EGFR and/or K-RAS are mutated, they may cause transformation of ATII cells. (b) In vitro A549 model proposed from the current study. A549 has been demonstrated to have K-RAS mutation (G12S) and EGFR amplification. In A549 clones, B7 have characters of ATII cell, and H12 have characters of both ATI and ATII cells. Both B7 and H12 can be enhanced the cell-type-specific markers of ATII-like cells by treatment of U0126 + DCIK. Injury, TGF- $\beta$, and IGF-1 may regulate differentiation from ATII-like cells into ATI-like cells. Black arrow: direction of differentiation; red arrow: experimental stimuli; dotted arrow: hypothesis. Yellow oval: nuclei of normal cells; black oval: nuclei of cancer cells; gray oval: nuclei of differentiated clones.

the potential representatives of bipotent ATI/II and ATII cells and would elucidate the molecular basis for ATII self-renewal and differentiation from ATII cells into ATI cells.

\section{Conclusions}

In this study, we isolated A549 clones and characterized their distinct characteristics in morphology and gene expression patterns. Among them, we found that two A549 clones, B7 and H12, have ATII cell- and ATI/ATII cell-like characteristics, and they were responsive to the serum depleted stimuli, suggesting that they have the plasticity in gene expression of alveolar differentiation markers. These A549 clones could become the sources of model system to study the molecular basis of regulation for ATII differentiation.

\section{Conflict of Interests}

The authors declare that there is no conflict of interests regarding the publication of this paper.

\section{Authors' Contribution}

Hiroshi Kondo and Keiko Miyoshi contributed equally to this work.

\section{Acknowledgments}

This work was partly supported by the Presidential Research Budget of the University of Tokushima. The authors thank Prof. Issei Imoto in the Department of Human Genetics, 
The University of Tokushima for cell authentication. The authors also thank the Support Center for Advanced Medical Sciences, Institute of Health Biosciences, the University of Tokushima Graduate School.

\section{References}

[1] T. G. Liou, S. M. Raman, and B. C. Cahill, "Lung transplantation for chronic obstructive pulmonary disease," Transplant Research and Risk Management, vol. 2013, no. 5, pp. 1-20, 2013.

[2] D. Siniscalco, N. Sullo, S. Maione, F. Rossi, and B. D'Agostino, "Stem cell therapy: the great promise in lung disease," Therapeutic Advances in Respiratory Disease, vol. 2, no. 3, pp. 173-177, 2008.

[3] A. Tzouvelekis, G. Laurent, and D. Bouros, "Stem cell therapy in chronic obstructive pulmonary disease. Seeking the prometheus effect," Current Drug Targets, vol. 14, no. 2, pp. 246252, 2013.

[4] M. Ghaedi, E. A. Calle, J. J. Mendez et al., "Human iPS cell-derived alveolar epithelium repopulates lung extracellular matrix," The Journal of Clinical Investigation, vol. 123, no. 11, pp. 4950-4962, 2013.

[5] S. X. L. Huang, M. N. Islam, J. O’Neill et al., "Efficient generation of lung and airway epithelial cells from human pluripotent stem cells," Nature Biotechnology, vol. 32, no. 1, pp. 84-91, 2014.

[6] M. C. Williams, "Alveolar type I cells: molecular phenotype and development," Annual Review of Physiology, vol. 65, pp. 669695, 2003.

[7] K. Dahlin, E. M. Mager, L. Allen et al., "Identification of genes differentially expressed in rat alveolar type I cells," American Journal of Respiratory Cell and Molecular Biology, vol. 31, no. 3, pp. 309-316, 2004.

[8] S. M. Kreda, M. C. Gynn, D. A. Fenstermacher, R. C. Boucher, and S. E. Gabriel, "Expression and localization of epithelial aquaporins in the adult human lung," American Journal of Respiratory Cell and Molecular Biology, vol. 24, no. 3, pp. 224234, 2001.

[9] L. DeMaio, W. Tseng, Z. Balverde et al., "Characterization of mouse alveolar epithelial cell monolayers," American Journal of Physiology_Lung Cellular and Molecular Physiology, vol. 296, no. 6, pp. L1051-L1058, 2009.

[10] G. R. Newman, L. Campbell, C. von Ruhland, B. Jasani, and M. Gumbleton, "Caveolin and its cellular and subcellular immunolocalisation in lung alveolar epithelium: implications for alveolar epithelial type I cell function," Cell and Tissue Research, vol. 295, no. 1, pp. 111-120, 1999.

[11] N. Demling, C. Ehrhardt, M. Kasper, M. Laue, L. Knels, and E. P. Rieber, "Promotion of cell adherence and spreading: a novel function of RAGE, the highly selective differentiation marker of human alveolar epithelial type I cells," Cell and Tissue Research, vol. 323, no. 3, pp. 475-488, 2006.

[12] J. R. Rock and B. L. M. Hogan, "Epithelial progenitor cells in lung development, maintenance, repair, and disease," Annual Review of Cell and Developmental Biology, vol. 27, pp. 493-512, 2011.

[13] H. Fehrenbach, "Alveolar epithelial type II cell: defender of the alveolus revisited," Respiratory Research, vol. 2, no. 3, pp. 475488, 2006.

[14] F. Possmayer, "A proposed nomenclature for pulmonary surfactant-associated proteins," American Review of Respiratory Disease, vol. 138, no. 4, pp. 990-998, 1988.
[15] Y. Kuroki and D. R. Voelker, "Pulmonary surfactant proteins," The Journal of Biological Chemistry, vol. 269, no. 42, pp. 2594325946, 1994.

[16] T. Yamaguchi, Y. Hosono, K. Yanagisawa, and T. Takahashi, "NKX2-1/TTF-1: an enigmatic oncogene that functions as a double-edged sword for cancer cell survival and progression," Cancer Cell, vol. 23, no. 6, pp. 718-723, 2013.

[17] V. Boggaram, "Thyroid transcription factor-1 (TTF-1/Nkx2.1/ TITF1) gene regulation in the lung," Clinical Science, vol. 116, no. 1, pp. 27-35, 2009.

[18] R. J. Bohinski, R. Di Lauro, and J. A. Whitsett, “The lung-specific surfactant protein B gene promoter is a target for thyroid transcription factor 1 and hepatocyte nuclear factor 3 , indicating common factors for organ-specific gene expression along the foregut axis," Molecular and Cellular Biology, vol. 14, no. 9, pp. 5671-5681, 1994.

[19] S. E. Kelly, C. J. Bachurski, M. S. Burhans, and S. W. Glasser, "Transcription of the lung-specific surfactant protein $C$ gene is mediated by thyroid transcription factor 1," The Journal of Biological Chemistry, vol. 271, no. 12, pp. 6881-6888, 1996.

[20] J. V. Degiulio, C. D. Kaufman, and D. A. Dean, "The SPC promoter facilitates alveolar type II epithelial cell-specific plasmid nuclear import and gene expression," Gene Therapy, vol. 17, no. 4, pp. 541-549, 2010.

[21] M. J. Evans, L. J. Cabral, R. J. Stephens, and G. Freeman, "Renewal of alveolar epithelium in the rat following exposure to $\mathrm{NO}_{2}$," The American Journal of Pathology, vol. 70, no. 2, pp. 175-198, 1973.

[22] B. D. Uhal, "Cell cycle kinetics in the alveolar epithelium," The American Journal of Physiology, vol. 272, no. 6, part 1, pp. L1031L1045, 1997.

[23] L. B. Ware and M. A. Matthay, "The acute respiratory distress syndrome," The New England Journal of Medicine, vol. 342, no. 18, pp. 1334-1349, 2000.

[24] G. R. Clegg, C. Tyrrell, S. R. McKechnie, M. F. Beers, D. Harrison, and M. C. McElroy, "Coexpression of RTI40 with alveolar epithelial type II cell proteins in lungs following injury: identification of alveolar intermediate cell types," American Journal of Physiology_Lung Cellular and Molecular Physiology, vol. 289, no. 3, pp. L382-L390, 2005.

[25] T. J. Desai, D. G. Brownfield, and M. A. Krasnow, "Alveolar progenitor and stem cells in lung development, renewal and cancer," Nature, vol. 507, no. 7491, pp. 190-194, 2014.

[26] C. E. Barkauskas, M. J. Cronce, C. R. Rackley et al., “Type 2 alveolar cells are stem cells in adult lung," The Journal of Clinical Investigation, vol. 123, no. 7, pp. 3025-3036, 2013.

[27] D. M. Valenzuela and J. Groffen, "Four human carcinoma cell lines with novel mutations in position 12 of c-K-ras oncogene," Nucleic Acids Research, vol. 14, no. 2, pp. 843-852, 1986.

[28] M. Krypuy, G. M. Newnham, D. M. Thomas, M. Conron, and A. Dobrovic, "High resolution melting analysis for the rapid and sensitive detection of mutations in clinical samples: KRAS codon 12 and 13 mutations in non-small cell lung cancer," BMC Cancer, vol. 6, article 295, 2006.

[29] J. Amann, S. Kalyankrishna, P. P. Massion et al., "Aberrant epidermal growth factor receptor signaling and enhanced sensitivity to EGFR inhibitors in lung cancer," Cancer Research, vol. 65, no. 1, pp. 226-235, 2005.

[30] M. Lieber, B. Smith, A. Szakal, W. Nelson-Rees, and G. Todaro, "A continuous tumor cell line from a human lung carcinoma with properties of type II alveolar epithelial cells," International Journal of Cancer, vol. 17, no. 1, pp. 62-70, 1976. 
[31] V. Kolla, L. W. Gonzales, J. Gonzales et al., "Thyroid transcription factor in differentiating type II cells: regulation, isoforms, and target genes," American Journal of Respiratory Cell and Molecular Biology, vol. 36, no. 2, pp. 213-225, 2007.

[32] I. R. Witherden, E. J. V. Bon, P. Goldstraw, C. Ratcliffe, U. Pastorino, and T. D. Tetley, "Primary human alveolar type II epithelial cell chemokine release: effects of cigarette smoke and neutrophil elastase," American Journal of Respiratory Cell and Molecular Biology, vol. 30, no. 4, pp. 500-509, 2004.

[33] M. V. Croce, A. G. Colussi, M. R. Price, and A. Segal-Eiras, "Identification and characterization of different subpopulations in a human lung adenocarcinoma cell line (A549)," Pathology \& Oncology Research, vol. 5, no. 3, pp. 197-204, 1999.

[34] Z. Rucka, P. Vanhara, I. Koutna et al., "Differential effects of insulin and dexamethasone on pulmonary surfactantassociated genes and proteins in A549 and H441 cells and lung tissue," International Journal of Molecular Medicine, vol. 32, no. 1, pp. 211-218, 2013.

[35] R. E. Scott, C.-Y. Tzen, M. M. Witte, S. Blatti, and H. Wang, "Regulation of differentiation, proliferation and cancer suppressor activity," The International Journal of Developmental Biology, vol. 37, no. 1, pp. 67-74, 1993.

[36] G. L. Semenza, "Targeting HIF-1 for cancer therapy," Nature Reviews Cancer, vol. 3, no. 10, pp. 721-732, 2003.

[37] Q. Ke and M. Costa, "Hypoxia-inducible factor-1 (HIF-1)," Molecular Pharmacology, vol. 70, no. 5, pp. 1469-1480, 2006.

[38] D. T. Dang, F. Chen, L. B. Gardner et al., "Hypoxiainducible factor- $1 \alpha$ promotes nonhypoxia-mediated proliferation in colon cancer cells and xenografts," Cancer Research, vol. 66, no. 3, pp. 1684-1693, 2006.

[39] J. Brognard and P. A. Dennis, "Variable apoptotic response of NSCLC cells to inhibition of the MEK/ERK pathway by small molecules or dominant negative mutants," Cell Death and Differentiation, vol. 9, no. 9, pp. 893-904, 2002.

[40] J. Niu, Q. Mo, H. Wang, M. Li, J. Cui, and Z. Li, "Invasion inhibition by a MEK inhibitor correlates with the actin-based cytoskeleton in lung cancer A549 cells," Biochemical and Biophysical Research Communications, vol. 422, no. 1, pp. 80-84, 2012.

[41] T. A. Longmire, L. Ikonomou, F. Hawkins et al., "Efficient derivation of purified lung and thyroid progenitors from embryonic stem cells," Cell Stem Cell, vol. 10, no. 4, pp. 398-411, 2012.

[42] S. Gotoh, I. Ito, T. Nagasaki et al., "Generation of alveolar epithelial spheroids via isolated progenitor cells from human pluripotent stem cells," Stem Cell Reports, vol. 3, no. 3, pp. 394403, 2014.

[43] L. W. Gonzales, S. H. Guttentag, K. C. Wade, A. D. Postle, and P. L. Ballard, "Differentiation of human pulmonary type II cells in vitro by glucocorticoid plus cAMP," American Journal of Physiology_Lung Cellular and Molecular Physiology, vol. 283, no. 5, pp. L940-L951, 2002.

[44] P. L. Ballard, J. W. Lee, X. Fang et al., "Regulated gene expression in cultured type II cells of adult human lung," American Journal of Physiology —Lung Cellular and Molecular Physiology, vol. 299, no. 1, pp. L36-L50, 2010.

[45] C. D. Foster, L. S. Varghese, R. B. Skalina, L. W. Gonzales, and S. H. Guttentag, "In vitro transdifferentiation of human fetal type II cells toward a type I-like cell," Pediatric Research, vol. 61, no. 4, pp. 404-409, 2007.

[46] K. A. Foster, C. G. Oster, M. M. Mayer, M. L. Avery, and K. L. Audus, "Characterization of the A549 cell line as a type II pulmonary epithelial cell model for drug metabolism," Experimental Cell Research, vol. 243, no. 2, pp. 359-366, 1998.

[47] M. E. Winkler, C. Mauritz, S. Groos et al., "Serum-free differentiation of murine embryonic stem cells into alveolar type II epithelial cells," Cloning and Stem Cells, vol. 10, no. 1, pp. 49-64, 2008.

[48] R. S. Herbst, J. V. Heymach, and S. M. Lippman, "Molecular origins of cancer: lung cancer," The New England Journal of Medicine, vol. 359, no. 13, pp. 1367-1380, 2008.

[49] M. F. Favata, K. Y. Horiuchi, E. J. Manos et al., "Identification of a novel inhibitor of mitogen-activated protein kinase kinase," The Journal of Biological Chemistry, vol. 273, no. 29, pp. 1862318632, 1998.

[50] D. T. Dudley, L. Pang, S. J. Decker, A. J. Bridges, and A. R. Saltiel, "A synthetic inhibitor of the mitogen-activated protein kinase cascade," Proceedings of the National Academy of Sciences of the United States of America, vol. 92, no. 17, pp. 7686-7689, 1995.

[51] C. Lauand, P. Rezende-Teixeira, B. A. Cortez, E. L. D. O. Niero, and G. M. Machado-Santelli, "Independent of ErbB1 gene copy number, EGF stimulates migration but is not associated with cell proliferation in non-small cell lung cancer," Cancer Cell International, vol. 13, no. 1, article 38, 2013.

[52] P. W. Cook, P. A. Mattox, W. W. Keeble et al., "A heparin sulfateregulated human keratinocyte autocrine factor is similar or identical to amphiregulin," Molecular and Cellular Biology, vol. 11, no. 5, pp. 2547-2557, 1991.

[53] K. Hashimoto, S. Higashiyama, H. Asada et al., "Heparinbinding epidermal growth factor-like growth factor is an autocrine growth factor for human keratinocytes," The Journal of Biological Chemistry, vol. 269, no. 31, pp. 20060-20066, 1994.

[54] R. C. Harris, E. Chung, and R. J. Coffey, "EGF receptor ligands," Experimental Cell Research, vol. 284, no. 1, pp. 2-13, 2003.

[55] E. Kakiashvili, Q. Dan, M. Vandermeer et al., "The epidermal growth factor receptor mediates tumor necrosis factor$\alpha$-induced activation of the ERK/GEF-H1/RhoA pathway in tubular epithelium," The Journal of Biological Chemistry, vol. 286, no. 11, pp. 9268-9279, 2011.

[56] O. Warburg, "On the origin of cancer cells," Science, vol. 123, no. 3191, pp. 309-314, 1956.

[57] N. D. Amoêdo, M. F. Rodrigues, P. Pezzuto et al., "Energy metabolism in H460 lung cancer cells: effects of histone deacetylase inhibitors," PLoS ONE, vol. 6, no. 7, Article ID e22264, 2011.

[58] K. Sugahara, J. S. Rubin, R. J. Mason, E. L. Aronsen, and J. M. Shannon, "Keratinocyte growth factor increases mRNAs for SP-A and SP-B in adult rat alveolar type II cells in culture," American Journal of Physiology-Lung Cellular and Molecular Physiology, vol. 269, no. 3, part 2, pp. L344-L350, 1995.

[59] N. Chelly, O.-B. Mouhieddine-Gueddiche, A.-M. Barlier-Mur, B. Chailley-Heu, and J. R. Bourbon, "Keratinocyte growth factor enhances maturation of fetal rat lung type II cells," American Journal of Respiratory Cell and Molecular Biology, vol. 20, no. 3, pp. 423-432, 1999.

[60] Z. Borok, R. L. Lubman, S. I. Danto et al., "Keratinocyte growth factor modulates alveolar epithelial cell phenotype in vitro: expression of aquaporin 5," American Journal of Respiratory Cell and Molecular Biology, vol. 18, no. 4, pp. 554-561, 1998.

[61] S. Schmeckebier, C. Mauritz, K. Katsirntaki et al., "Keratinocyte growth factor and dexamethasone plus elevated cAMP levels synergistically support pluripotent stem cell differentiation into alveolar epithelial type II cells," Tissue Engineering Part A, vol. 19, no. 7-8, pp. 938-951, 2013. 
[62] W. Zhou, M. Choi, D. Margineantu et al., "HIFl $\alpha$ induced switch from bivalent to exclusively glycolytic metabolism during ESCto-EpiSC/hESC transition," The EMBO Journal, vol. 31, no. 9, pp. 2103-2116, 2012.

[63] L. Zhao, M. Yee, and M. A. O'Reilly, “Transdifferentiation of alveolar epithelial type II to type I cells is controlled by opposing TGF- $\beta$ and BMP signaling," American Journal of PhysiologyLung Cellular and Molecular Physiology, vol. 305, no. 6, pp. L409-L418, 2013.

[64] M. C. Ghosh, V. Gorantla, P. S. Makena et al., "Insulin-like growth factor-I stimulates differentiation of ATII cells to ATIlike cells through activation of Wnt5a," American Journal of Physiology_Lung Cellular and Molecular Physiology, vol. 305, no. 3, pp. L222-L228, 2013.

[65] N. O. Bianchi, "Y chromosome structural and functional changes in human malignant diseases," Mutation Research, vol. 682, no. 1, pp. 21-27, 2009.

[66] S. Vijayakumar, D. Garcia, C. H. Hensel et al., "The human Y chromosome suppresses the tumorigenicity of PC-3, a human prostate cancer cell line, in athymic nude mice," Genes Chromosomes \& Cancer, vol. 44, no. 4, pp. 365-372, 2005.

[67] S. Vijayakumar, D. C. Hall, X. T. Reveles et al., "Detection of recurrent copy number loss at Yp11.2 involving TSPY gene cluster in prostate cancer using array-based comparative genomic hybridization," Cancer Research, vol. 66, no. 8, pp. 4055-4064, 2006.

[68] L. A. Forsberg, C. Rasi, N. Malmqvist et al., "Mosaic loss of chromosome $\mathrm{Y}$ in peripheral blood is associated with shorter survival and higher risk of cancer," Nature Genetics, vol. 46, no. 6, pp. 624-628, 2014.

[69] K. Kemper, P. L. de Goeje, D. S. Peeper, and R. van Amerongen, "Phenotype switching: tumor cell plasticity as a resistance mechanism and target for therapy," Cancer Research, vol. 74, no. 21, pp. 5937-5941, 2014.

[70] G. J. Riely, J. Marks, and W. Pao, "KRAS mutations in non-small cell lung cancer," Proceedings of the American Thoracic Society, vol. 6, no. 2, pp. 201-205, 2009.

[71] M. D. Siegelin and A. C. Borczuk, "Epidermal growth factor receptor mutations in lung adenocarcinoma," Laboratory Investigation, vol. 94, no. 2, pp. 129-137, 2014. 

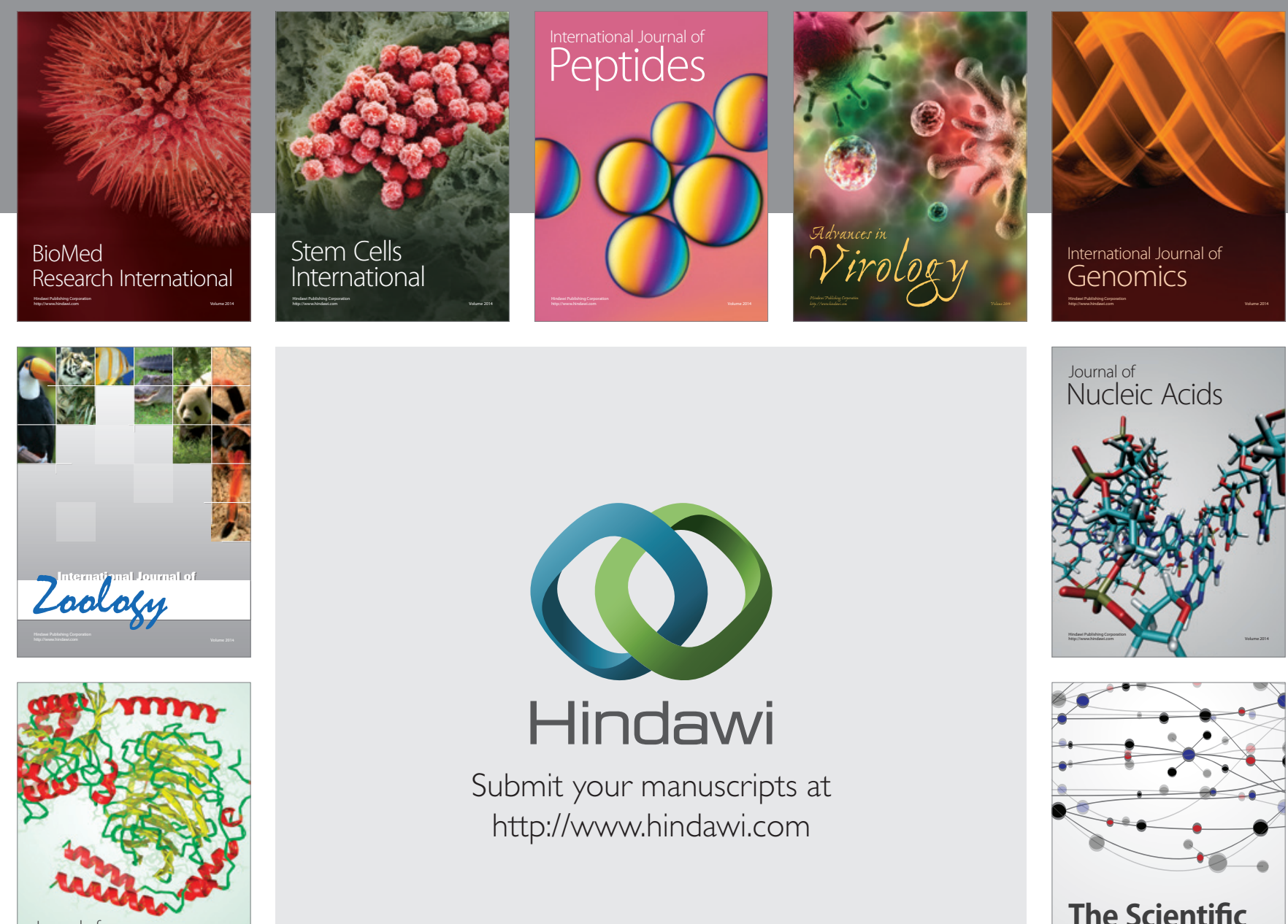

Submit your manuscripts at

http://www.hindawi.com

Journal of
Signal Transduction
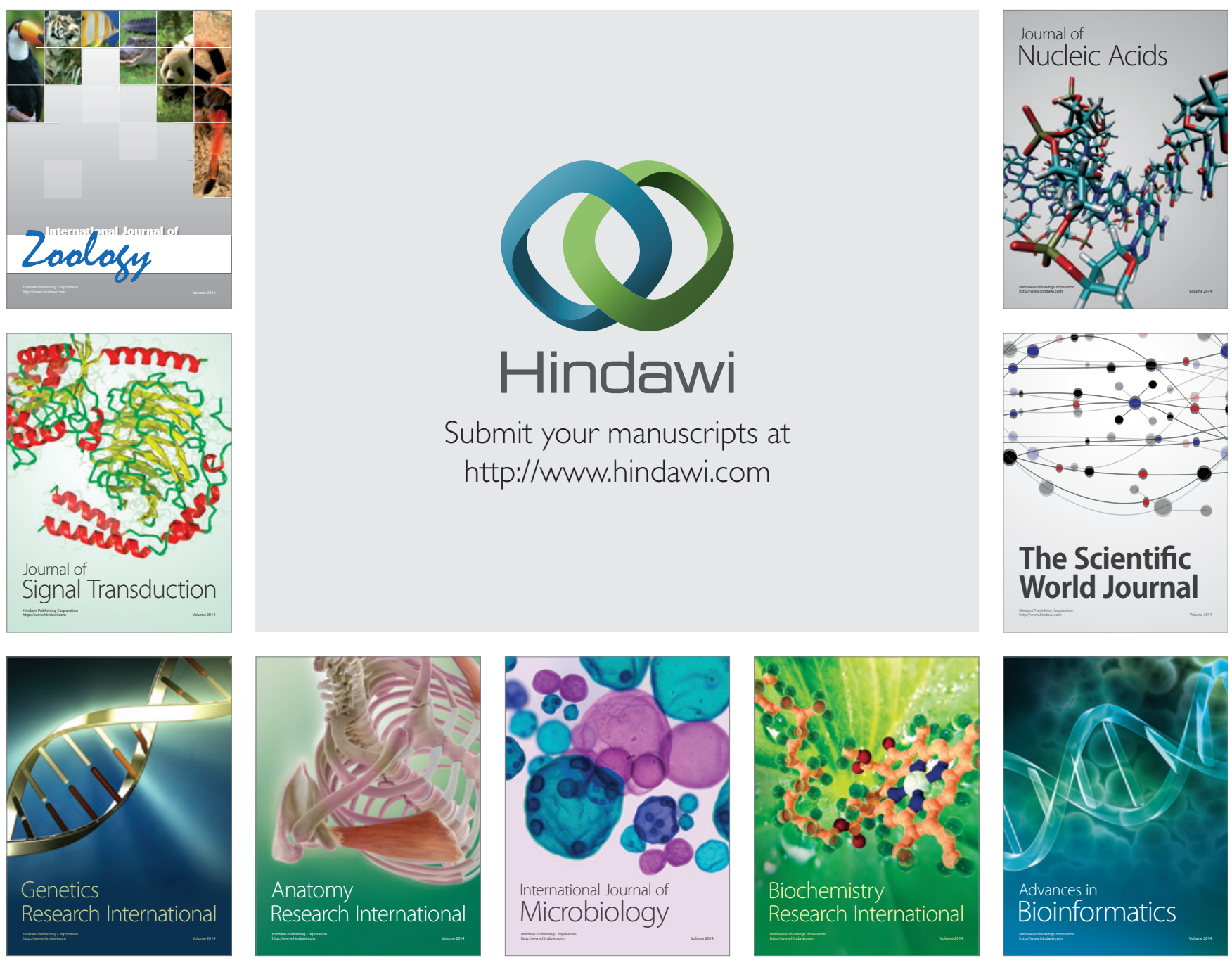

The Scientific World Journal
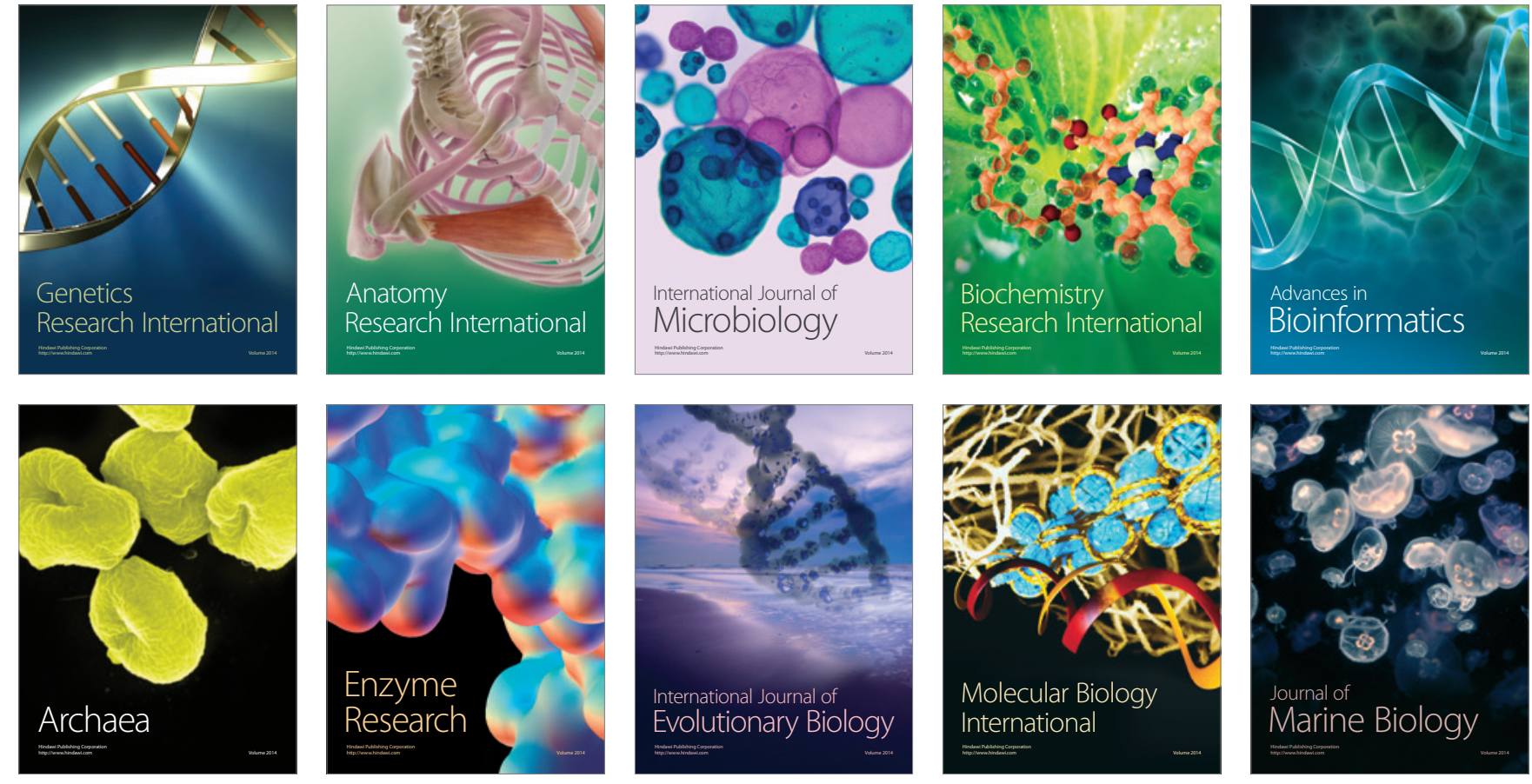